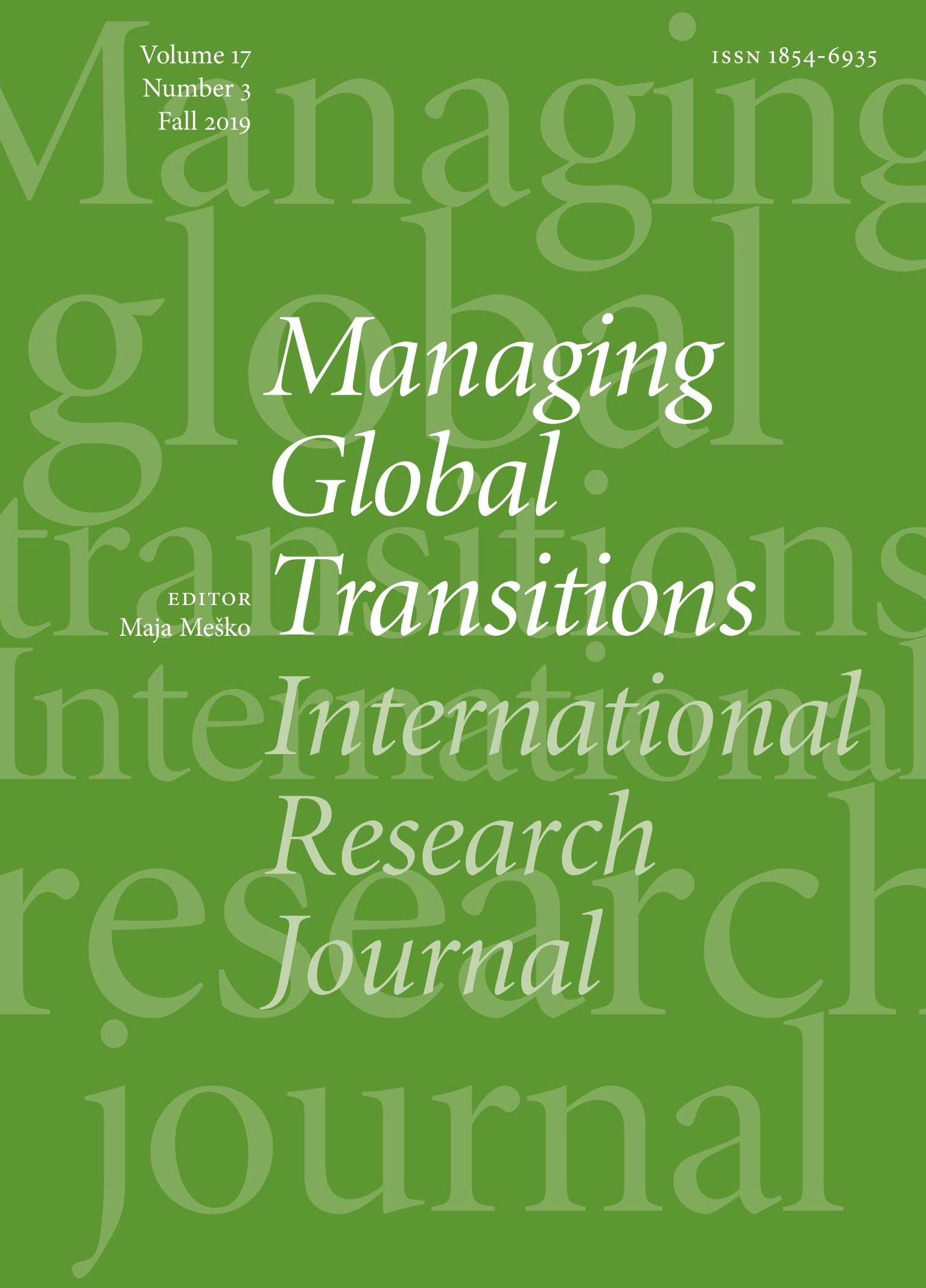




\section{Managing Global Transitions International Research Journal}

ISSN $1854-6935 \cdot$ www.mgt.fm-kp.si

EDITOR

Maja Meško, University of Primorska, Slovenia,maja.mesko@fm-kp.si

ASSOCIATE EDITORS

Andrej Bertoncelj, University of Primorska, Slovenia, andrej.bertoncelj@fm-kp.si

Gandolfo Dominici, University of Palermo, Italy,gandolfo.dominici@libero.it

Alexander Laszlo, Buenos Aires Institute of Technology, Argentina, alaszlo@itba.edu.ar

MANAGING AND PRODUCTION EDITOR

Alen Ježovnik, University of Primorska Press, Slovenia,alen.jezovnik@upr.si

EDITORIAL BOARD

Jani Bekő, Univerza v Mariboru, Slovenia, jani.beko@uni-mb.si

Heri Bezić, University of Rijeka, Croatia, bezic@efri.hr

Guido Bortoluzzi, University of Trieste, Italy, guido.bortoluzzi@deams.units.it

David L. Deeds, University of St. Thomas, usA,david.deeds@gmail.com

Evan Douglas, Griffith Universitiy, Australia, e.douglas@griffith.edu.au

Dean Fantazzini, Moscow School of Economics, Russia, fantazzini@mse-msu.ru

Henryk Gurgul, A GH University of Science and Technology, Poland, henryk.gurgul@gmail.com

András Inotai, Hungarian Academy of Sciences, Hungary, inotai.andras@krtk.mta.hu

Felicetta Iovino, University of Sannio, Italy, fiovino@unisannio.it

Hun Joon Park, Yonsei University, South Korea,hjpark@yonsei.ac.kr

Renata Karkowska, University of Warsaw, Poland,rkarkowska@wz.uw.edu.pl

Tanja Kosi Antolič, Institute of Macroeconomic Analysis and Development, Slovenia, tanja.kosi-antolic@gov.si
Leonard H. Lynn, Case Western Reserve University, UsA, leonard.lynn@case.edu Monty Lynn, Abilene Christian University, USA, monty.lynn@coba.acu.edu

Massimiliano Marzo, University of Bologna, Italy,massimiliano.marzo@unibo.it

Judita Peterlin, University of Ljubljana, Slovenia, judita.peterlin@ef.uni-lj.si

Mirjana Pejić Bach, University of Zagreb, Croatia,mpejic@efzg.hr

Sanja Peković, University of Crna Gora, Montenegro,psanja@ac.me

Sandra Penger, University of Ljubljana, Slovenia,sandra.penger@ef.uni-lj.si

Zdenko Prohaska, University of Rijeka, Croatia, zdenko.prohaska@efri.hr

José Solana Ibánez, Technical University of Cartagena, Spain, jose.solana@cud.upct.es

Marinko Škare, University of Pula, Croatia, mskare@unipu.hr

Nada Trunk Širca, International School of Social and Business Studies, Slovenia, trunk.nada@gmail.com

Šárka Velčovská, Technical University of Ostrava, Czech Republic, sarka.velcovska@vsb.cz

Manfred Weiss, Johann Wolfgang Goethe University, Germany, m.weiss@jur.uni-frankfurt.de

INDEXING AND ABSTRACTING

Managing Global Transitions is indexed/ listed in the International Bibliography of the Social Sciences, EconLit, I z Z Online, DoAJ, Erih Plus, EconPapers, Cabell's, EBsCO, and ProQuest.

SUPPORTED BY

Slovenian Research Agency.

Revija Managing Global Transitions je namenjena mednarodni znanstveni javnosti; izhaja $v$ angleščini s povzetki $v$ slovenščini. Izid revije je finančno podprla Javna agencija za raziskovalno dejavnost Republike Slovenije iz sredstev državnega proračuna iz naslova razpisa za sofinanciranje izdajanja domačih znanstvenih periodičnih publikacij. 


\section{Managing Global Transitions International Research Joumal}

VOLUME $17 \cdot$ NUMBER 3 · FALL 2O19 · ISSN 1854-6935

195 Importance of Culture for Sustainable Development Mitja Bervar and Anita Trnavčević

211 Influencer Marketing as a Modern Phenomenon in Reputation Management Josef Vodák, Martin Novysedlák, Lucia Čakanová, and Miroslav Pekár

221 Drivers that Impact the Merchants' Repeat Intention for Group Deal Promotions

Nina Angelovska, Sasho Josimovski, and Lidija Pulevska Ivanovska

239 Vision of Personal Future as a Tool for Supporting Adolescents' Transition to Adulthood Nada Polovina and Smiljana Jošić

259 Abstracts in Slovene 
AIMS AND SCOPE

Managing Global Transitions (MGT) is a quarterly, scholarly journal that covers diverse aspects of transitions and welcomes research on change and innovation in increasingly digitalized and networked economic environments, from a societal, organizational, and technological perspective. MGT fosters the exchange of ideas, experience and knowledge among developed and developing countries with different cultural, organizational and technological traditions. MGT invites conceptual, theorydevelopment, empirical and review papers and case-based studies advancing the field of transitions in societies, organizations and technologies.

\section{TOPICS COVERED}

\section{Transitions in Societies}

- Geo-political transitions, transition experiments, pathways and mechanisms

- Social, demographic, cross-cultural, ethical, geo-political and security aspects of transitions

- Social change, prosperity, wellbeing, happiness

- Policy making, government regulation, social responsibility

- Knowledge-based society and world futures

- New and emerging metrics for measuring, assessing and evaluating societal transitions

\section{Transitions in Organizations}

- Organizational analysis and design, modeling, developments and changes in organizational learning and behavior

- International strategy and strategic alliances, networked businesses and operations

- Entrepreneurship and leadership, decision making

- Knowledge sourcing and innovation management, personal development, education and training, HRM

- Business systems and business models

- Connective intelligence and collective intelligence in organizational behavior
Transitions in Technologies

- Managing technological/organizational change and innovation

- Technology networks, technology transfer benefits and risks, technology acquisition and diffusion

- Smart technologies and development discontinuities, renewable sources and sustainability

- Digitalization, гот, гст, cybernetics, forecasting

- Technological traditions, strategic surprise and response systems

- Studies that promote understanding of the dynamics of socio-technical systems change

- Science and technology policy that fosters transformative advancement

- Modeling technological change in vucA (volatile, uncertain, complex, ambiguous) environments

SUBMISSIONS

The manuscripts should be submitted as e-mail attachment to the editorial office at mgt@fm-kp.si. Detailed guide for authors and publishing ethics statement are available at www.mgt.fm-kp.si.

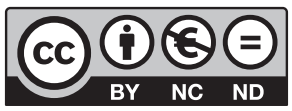

EDITORIAL OFFICE

University of Primorska

Faculty of Management

Cankarjeva 5, 6104 Koper, Slovenia

mgt@fm-kp.si · www.mgt.fm-kp.si

PUBLISHED BY

University of Primorska Press

Titov trg 4, 60oo Koper, Slovenia

zalozba@upr.si·www.hippocampus.si

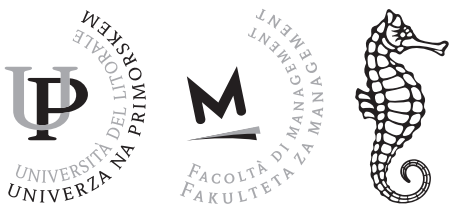




\section{Importance of Culture for Sustainable Development}

Mitja Bervar

мв zavod, Slovenia

mitja.bervar@gmail.com

Anita Trnavčević

University of Primorska, Slovenia

anita.trnavcevic@fm-kp.si

The aim of this paper is to investigate the importance and the role of culture in sustainable development. The study is based on a qualitative research on the quota sample of three referential groups of experts by using interview as a method of data collection. The findings of the study confirm that culture, as a holistic and complex system of values and creative potentials, stimulates social cohesion in society, strengthens intercultural dialogue as well as provides for economic effects, all of which is in turn reflected in sustainable development. We suggest the establishment of a fourth pillar, aside the economic, social and environmental, to be incarnated by culture. Key Words: sustainability, culture, social cohesion, intercultural dialogue, fourth pillar

JEL Classification: D63, E61, L38, Z10

https://doi.org/10.26493/1854-6935.17.195-209

\section{Introduction}

Sustainability is one of the key concepts in the European Union. It has been devoted the whole decade but recently more and more events reposition sustainability at the center of political issues and theoretical discussions. Greta Thunberg and her call that young people need home in the future - the Earth. Theoretically, in all areas of sustainable development on going publications in the field of environmental sciences, economy, and social sciences show the need for researchers to provide data for decision-makers. In political arena, sustainability and sustainable development are on the agenda of every major world summit, and also 'locally' at the level of nation states and local communities.

Sustainability is defined in the Brundtland Report as 'development that meets the needs and aspirations of the present without compromising the ability of future generations to meet their own needs' (United Nations World Commission on Environment and Development 1987, 43). 
Sustainable development has been commonly defined from the perspective of three interrelated dimensions, namely the economic, social and environmental (Kates, Parris, and Leserowitz 2005; Hasna 2007; Elliott 2013; Kordestani, Peighambari, and Foster 2015; Sachs 2015). In practice, sustainable development means searching for, debating and seeking compromise among different concepts and set priorities according to our value system, like the triple-bottom-line concept (3B L) and ecologically sustainable development concept (ESD) (Utting 2000; Savitz 2014; Apte and Sheth 2016).

A traditional conceptual framework of sustainable development has been lately expanded by the fourth pillar: culture (Hawkes 2001) thus recognizing the importance of cultural sustainability. In the European Union, the value system aspires sustainability. The debate about values in the past two decades, when Europeans have broadly embraced the concepts of sustainable development, has been a cultural debate. Namely, 'cultural vitality is as essential to a healthy and sustainable society as social equity, environmental responsibility and economic viability' (Hawkes $2001,7)$. Hence, social dimension of sustainable development is not sufficient to provide holistic view on sustainable development.

In the past, the role of culture on society development was largely ignored. Nowadays, that view has been changing as an extraordinary range of potential benefits of the concept of culture, like cohesion, engagement, belonging and distinctiveness, are being integrated into frameworks of sustainable development (Hawkes 2001, Segalas et al. 2009; Makarov 2010; Li in Pak 2010; Singer 2010; Shaharir 2012).

The new governance paradigm of four building blocks of sustainability, namely economic wellbeing, environmental harmonization, social justice and cultural vitality as basic requirements, can provide a final goal of any responsible policy resulting in a sustainable society (Lee 2016). In this respect, 'culture is not the decoration added' (Hawkes 2001,3) to basic needs of any society, but itself is the basic need.

It is the imperative that we include the concept of culture as a co-creator and promoter of sustainable development in terms of intercultural and interreligious dialogue in the society. Those partial solutions should give way to more comprehensive, holistic understanding and embracement of sustainability (UNESCO 2001; 2010; 2013). We need to incorporate cultural dimension, culture in action, into the concept of sustainable development as the fourth dimension due to interdependency of sustainable development and culture. The aim of this paper is to explore the impor- 
tance and the role of culture in sustainable development in the framework of European policies. The study is based on a qualitative research on the purposive sample of three referential groups of experts by using interview as a method of data collection.

\section{Culture as the Fourth Pillar of Sustainability}

Sir Edward B. Tyler, British anthropologist, provided already in 1871 a definition of culture as the complex whole which includes knowledge, belief, art, morals, law, custom, any other capabilities and habits acquired by man as a member of society. His work gave first outlines of a new discipline, known as culturology.

Culture is an all-embracing concept that refers to the way of life of individuals in a particular society. Culture is who we are and no development can be viable in long-term without culture (Frantzeskaki, Loorbach, and Meadowcroft 2012; United Nations 2012; UNESCO 2005; 2013).

In 1998, intergovernmental conference on cultural policies for development took place in Stockholm on the premise of 'culture being understood as the basis of development, the very notion of cultural policy has to be considerably broadened' (UNESCO 1998). The conference recognized twelve principles and placed the culture at the very center of long-term development policies, among others the interdependence of sustainable development and culture, cultural fulfillment of people, involvement in cultural life, dialogue between cultures, cultural creativity, cultural diversity and cultural pluralism, and creativity in societies (UNESCO 1998). Moreover, the conference adopted several policy objectives as a recommendation to governments worldwide while designing, promoting and implementing their long-term, i.e. sustainable development strategies.

The concept of culture has been embedded in, and enhancing, the paradigm of society of values and the very concept of sustainable development. Only sustainable culture shows needed vitality for enabling sustainable society. Therefore, the fourth pillar - cultural sustainability is the glue that binds society. (Hawkes 2001).

A framework of sustainable development based on four pillars of sustainability: economy (material well-being through sustainable economic growth), equity (social well-being though social cohesion), ecology (environmental well-being through natural harmonization) and culture (cultural well-being through intercultural dialogue) is proposed (figure 1).

Hence, four pillars of sustainability have to become formally adopted around the globe: environmental sustainability, social sustainability, eco- 


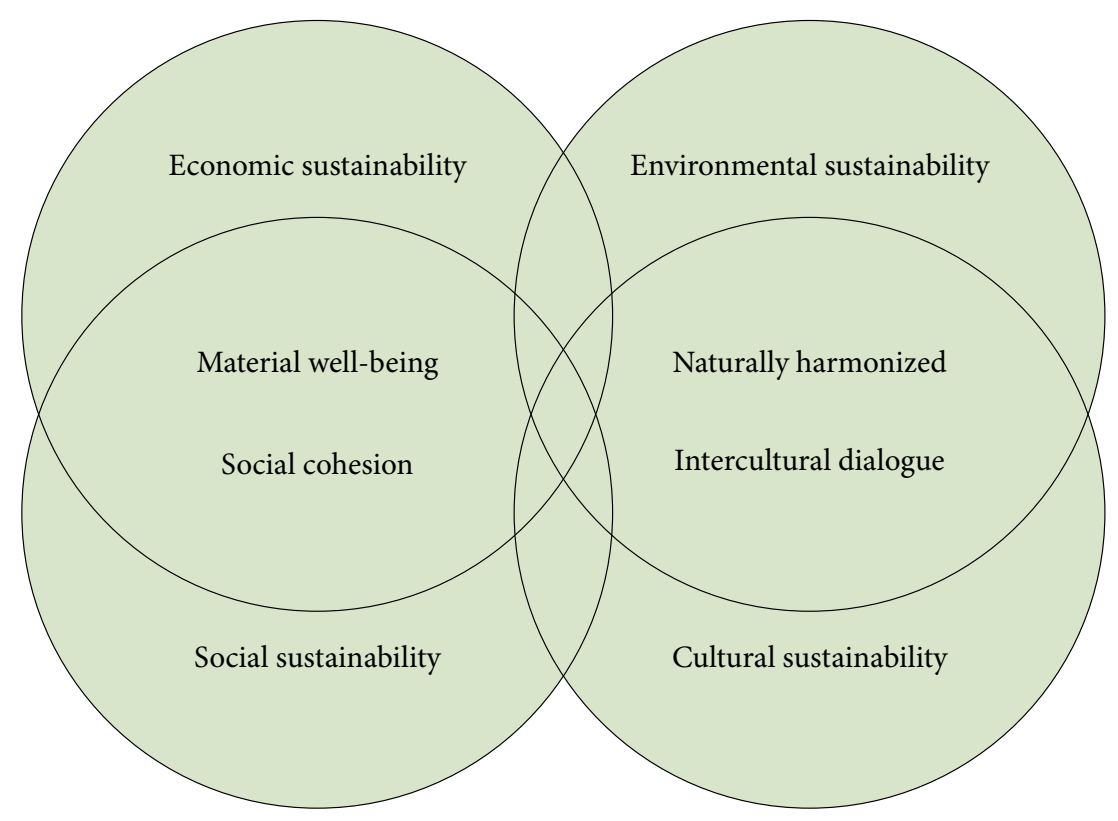

FIGURE 1 Four Pillar Concept of Sustainability

nomic sustainability and cultural sustainability (Yencken and Wilkinson 2000).

\section{CULTURE AS PROMOTER OF INTERCULTURAL DIALOGUE}

Intercultural dialogue, in its essence, 'seeks linkages and common ground between different cultures, communities, and people, promoting understanding and interaction' (European Commission 2008).

A precondition for promoting intercultural dialogue and bringing communities together is a commitment of all stakeholders for full cooperation and openness to cultural diversity and dialogue in order to avoid conflicts. In this respect, media has an important meditating role in intercultural dialogue as it not only greatly influences what we think, but also how we act. The use of information and communication technology (IC T) enables different cultures to interact with the contemporary world, to express themselves on their own terms and, hopefully, advance mutual knowledge, understanding and tolerance (Yarbrough 2011; Joyce, Vincze, and Marton 2016).

Culture plays an important role in the process of integrating migrants (Kearns and Whitley 2015; Ucok-Sayrak 2016), to help them better under- 
stand interactions with their new socio-cultural environment, thus contributing to more cohesive society by avoiding the tenacity of prejudice. Intercultural dialogue is a corrective to the diversity of our cultural intolerance and stereotypes on one side, but involves cultural tensions between people and communities on the other side when values and collective memory are involved (Human Rights Council 2007).

So what went wrong with the intercultural dialogue in the past? According to Schoefthaler (2006), intercultural dialogue has largely failed because of its focus on what is 'in common' rather than on differences and diversity. Mutual tolerance and respect rather than mere acceptance of diversity is needed (Schoefthaler 2006). According to the United Nations avoiding the deepening of existing stereotypes is the preferred way, all cultures should receive equal dignity. World of the 21st century is becoming increasingly multicultural. According to Huntington (1993 22), 'the great division among humankind and the dominating source of conflict will be cultural. The 'clash of civilizations' will dominate world politics. Or alternatively, the co-existence will prevail as different civilizations as cultural entities will have to learn how to live with the others. A shift from clash toward alliance of civilization is needed.

Intercultural dialogue is dependent on intercultural competencies, defined as 'complex of abilities needed to perform effectively and appropriately when interacting with those who are linguistically and culturally different from oneself' (Fantini 2007). In an intercultural dialogue, three basic capabilities are required to be efficient, namely listening capability, dialogue capability and wonder capability (Eberhard 2008).

Several new initiatives for intercultural and interfaith dialogue have been started in recent years. According to Eberhard (2008) the engagement in the process of dialogue should include our basic abilities to listen, wonder and dialogue.

\section{IMPORTANCE OF CULTURE FOR SOCIAL COHESION}

Social cohesion is commonly defined as the glue that keeps societies together. The European Union has experienced the challenges of not only economic globalization but also cultural globalization. In addition to more recent mass migration concerns and security threats, both having an (negative) impact on the stability of the society. The issue of social trust has emerged along with the need to be measured over time (Larsen 2014).

A modern globalized and multicultural world is also a world full of 
economic and financial crises. As a similarity of mind is difficult to achieve, it should at least be cultivated. Hence, culture can help in times of increased interdependence by promoting values of social inclusion and the idea of non-discrimination, tolerance and respect for diversity (Throsby 1999; Sage 2013; Mulunga and Yazdanifard 2014; Marrion 2016). Promotion of economic and social cohesion should be one of the priorities that guide our activities (Commission of European Communities 1994; Throsby 2001; Bueno, Salmador, and Rodríguez 2007; Brad et al. 2016). The EU's cohesion policy aims to help regions with the EU structural funds to achieve their full potential in order to bring about a convergence of living standard and prosperity and to reduce regional disparities (European Commission 2001; 2008; 2009 and 2011; OECD 2011; Støvring 2012; Wells in Lixinski 2016).

'The concept of culture provides the intellectual tools with which a more effective structure can be build' (Hawkes 2001, 1). A range of concepts that have developed in parallel, can be brought together and developed further, including the concept of cohesion and socially-held values (sense of purpose and meaning). Cultural diversity is essential component of social cohesion (coexistence) and economic cohesion (prosperity). Both, cultural and economic inequities need to be addressed, cultural democracy will have to occur. 'Cultural capital is the glue that holds a society together, social capital is the lubricant that allows it to operate smoothly' (Hawkes 2001, 18).

Economic development can be seen as a window of opportunity to increase social cohesion, but in itself it is not a sufficient condition (Larsen 2014). Social trust and multicultural dialogue are also needed for social integration and social cohesion. European union seeks for common policies on sustainable development however there are numerous questions and issues that need to discussed, dialogued and resolved at the nation states' levels and under national jurisdiction. Although, generaly speaking, there is basically no political person speaking against sustainable development in European Union there are varieties of solutions and understandings how sustainable development needs to be implemented. In Slovenia, there has not been a study that would engage the experts from different areas on issues related to cultural sustainability.

\section{Research Methodology}

Qualitative research approach (Yin 1984) was selected to execute the study of cultural sustainability in Slovenia as we wanted to gain insight 
into the personal understanding of the research problem by policy makers, experts and executive managers, thus focusing on studying the subjective meaning that selected participants attributed to the studied aspect of culture sustainability.

Quota sampling was used as a method for selecting participants based on their professional experience and knowledge in relation to the research problem. Participants were segmented into three homogeneous groups and semi-structured interviews (Galletta and Cross 2013) were conducted, each lasting from 60 to 90 minutes. The interview protocol was comprised of 20 questions divided into 2 sections. The interviews were tape recorded with participants' consent and transcribed. Participants were properly anonymized.

First group of participants in the study was comprised of five executive managers with the long-term experience and/or good knowledge and support of the culture sector.

Second group of participants in the study was comprised of six experts with the long-term experience in program planning, education, cultural heritage advisory, non-governmental organizations, authors' rights segment, management of public arts organization.

Third group of participants in the study was comprised of five policy makers, including three former ministers for culture, counsels and members of the national council for culture.

\section{RESEARCH QUESTIONS}

The following research questions were framed for the study:

1. What importance participants in the study give to culture as a fourth building block of sustainable development?

2. How do participants in the study describe importance of culture for social cohesion?

3. How do participants in the study describe importance of culture for intercultural dialogue?

\section{Results and Discussion}

PARTICIPANT OPINION ON IMPORTANCE OF CULTURE FOR SUSTAINABLE DEVELOPMENT

The responses of participants that attempted to identify the aspects with which culture contributed to the sustainable development of society were multifaceted. No participant expressed the opinion that culture does not 
contribute to sustainable development, and one even stated that culture in the broadest sense is crucial for understanding the importance of sustainable development. They emphasized that culture, as the bearer of identity in society, creates a system of values that it is a social binder to promote creativity and innovation at different levels of life, to promote social criticism and open spaces of dialogue, and to carry the potential of conflict prevention in itself, as it helps to break down tensions at the symbolic level.

At the same time, the participants warned about the need to search for added value, synergistic effects in linking culture with other fields. They expressed themselves critically about the lack of political will or competence of political decision-makers to place culture in the development strategies, as well as about high passivity of stakeholders in the field of culture, which would place responsibility for it too much in the hands of politics, depending on funding. They also warned that culture, in the absence of an imminent system of values, can also mean a security threat, a threat to the devastation of civilization, and warn against the instrumentalization of culture.

Participants recognized in the culture the potential for identity enhancement, the promotion of a creative, innovative and inclusive society, openness to the difference, recognized it a preventative role in preventing future financial and social crises, an important role in health prevention, and even in preventing conflicts and security risks. They linked it with social development, and recognized it as a 'generator of creativity' and a prerequisite for social cohesion.

The participants answered that cultural capital is the materialization of creativity and acquired knowledge. It is the result of a long-lasting development of society and contains a wealth of cultural heritage of nations or the global community. According to the interlocutors, cultural capital is an imminent component of the developmental level of society, and at the same time it is a strong anchorage of the individual in the community. Some people perceive this individual as the greatest cultural capital. Participants also mentioned the link between cultural and social capital and the level of tolerance in society.

PARTICIPANT OPINION ON CULTURE AS A PROMOTER OF SOCIAL COHESION

The study shows that almost all participants are well acquainted with the field. They have been actively involved in cultural projects in their per- 
sonal or business life in order to promote social cohesion. The general belief of participants is that culture is a strong community binder. In this context, they draw attention to its inclusive nature, which enables cultural institutions to become places of dialogue and confront with differences, a culture of the inclusion of the inclusive society and the quality of life in it. Accessibility of culture and active participation in it strengthens the individual's image, allows him to travel from the margin and gives a sense of inclusion, acceptance. It can therefore also be a powerful factor of the prevention on area of health and safety.

According to our interlocutors, social cohesion is created when people are exposed to the common experience that connects them. Although modern democracy and a lifestyle at the global level enable less of this kind of experience, amateur culture throughout the Slovenian cultural space lives an intense life and is established as a strong connecting element of the community. According to the participants, top-notch arts should be widely available, with the particular care and sensitivity for the young people.

\section{PARTICIPANT OPINION ON CULTURE AS A PROMOTER \\ OF INTERCULTURAL DIALOGUE}

Despite the fact that humanity faces daily with a lack of dialogue, three participants have expressed the view that the concept of intercultural dialogue is inadequate because it is obsolete, is no more than just a fashionable phrase. They believe it should be replaced by the term cultural coexistence. Participant, who expressed a negative attitude towards the notion, at the same time stressed the exceptional importance of intercultural dialogue in a globalized world, for which culture has no exclusive right and no responsibility.

Participants from the business world unanimously agreed on the importance of intercultural dialogue for successful business cooperation and coexistence, and recognized culture as a bridge between diverse cultures. They emphasized that successful business practices are those that allow diversity, which build trust on common values and establish dialogue while promoting coexistence and awareness of the importance of providing linguistic diversity for business success. Intercultural dialogue was marked as a way to learn about the values and customs of other nations, or even as the only survival option. Participants from the field of culture and related sectors emphasized the importance of a creative culture of cooperation that connects diverse cultures, since in the intercul- 
tural co-operation a global culture with global phenomena, values and ethics is emerging, it has drawn attention to the wealth of talents brought to society by various individuals and communities and thus enable hybridization and innovation in the field of artistic creation.

\section{Discussion and Future Directions}

Based on the results of the study the following interpretation is given:

1. Culture contributes to sustainable development. It has been unequivocally established that culture contributes to the sustainable development. It is more difficult to accurately determine its concrete effects, because due to the lack of comparable and relevant criteria, we often find ourselves on the slippery ground of justification more based on convictions than concrete indicators. There is a high degree of consensus that culture represents the code of the system of one's own values, while at the same time it acts as a social binder in the community, broadens its horizons, and strengthens the dialogue of openness to difference. Participation in cultural activities promotes creativity and innovation in all fields of operation, improves quality of life, prevails in many areas, and triggers special synergy effects when connecting with other fields.

2. Term cultural capital needs further clarification. Participants understood the concept of cultural capital in two ways, such as the materialization of creativity in cultural heritage and in the acquired skills on the one hand, and the profits from cultural activity on the other.

3. Active participation contributes to social cohesion. It is evident that the accessibility of culture and active participation reinforce the individual's image, enable the way out of the marginal areas to vulnerable groups and individuals, and encourage acceptance. Therefore, culture can also be a powerful factor in the prevention of health and safety. The importance of a culture for social cohesion and the democratization of society are particularly important in times of crisis.

4. Cultural cooperation promotes intercultural dialogue. Cultural cooperation successfully overcomes stereotypes, helps to understand the values and customs of other nations in a spirit of respect and coexistence, and stimulates the promotion of cultural and linguistic diversity, thus developing the intercultural competences of all stakeholders in the dialogue process. Creative intercultural cooperation can link diverse cultures at the symbolic level, help to resolve con- 
flicts between cultures or between subcultures, while at the same time promoting the wealth of talents that diverse individuals and communities bring to society, enables hybridization and innovation in the field of artistic creation.

5. Systemic solution is needed. The study confirms the contribution of the cultural and creative sectors and related sectors for economic development. The contribution to culture represents an investment in sustainable development and the stimulation of self-confidence and the innovative entrepreneurship of its citizens on the other hand. However, the potential for creative partnerships between creators and the economy in comparison with the international space in Slovenia remain underused.

6. Paradigm change is needed. To change the paradigm, both political will and qualification of the political decision makers are needed. It is only in view of both aspects that it would be possible to restore the fragile confidence of the cultural and creative sector and to establish stronger partnerships with it.

Based on the results of the study the following six future directions for policy makers are proposed:

1. Integrate culture into sustainable development strategies and raise awareness of its role by involving all stakeholders.

2. Create partnerships between cultural policy makers and stakeholders. It should be built on mutual trust. Provide financial resources and continuously monitor and evaluate progress.

3. Engage cultural policy makers in overcoming sectoral confusion and promote cross-sectoral cooperation in the fields of education, economy, social affairs, youth policies, development policies and other relevant areas.

4. Establish good practices tailor-made to the needs of stakeholders.

5. Take advantage of the openness and diversity of the natural and cultural heritage of the Slovene territory and offer the pulse of contemporary culture.

6. Empower cultural and creative sector and strengthen its competitiveness.

\section{Conclusion}

Culture can offer answers to global challenges of today's world. The path to cultural sustainability leads through the integration of art and culture 
into all stages of the education process, it is promoted by vibrant contacts with art and heritage and by active participation in cultural projects. Accessibility of culture and participation in it enable individuals to focus on the community, improve self-esteem and at the same time strengthen their responsibility to the community through active citizenship.

Because of its immanent nature, culture encourages and preserves an inclusive, creative and innovative society. The findings of our study affirm the claim about the importance of culture in promotion of sustainable intercultural dialogue. It is necessary to move on from lip service about intercultural dialogue to actually do more in this direction.

Culture, which is a value in itself, also offers a tool for establishing and strengthening intercultural competences. Collaboration in culture makes it possible to open up horizons, discover unknown worlds, learn other cultures, learn languages and make friends. It is the best way to overcome stereotypes and prejudices. The process of intercultural awareness and cooperation is particularly important for young people who will be part of future, hopefuly sustainable society, and therefore special attention should be paid to them.

\section{References}

Apte, S., and J. Sheth. 2016. The Sustainability Edge: How to Drive TopLine Growth with Triple-Bottom-Line Thinking. Toronto: University of Toronto Press.

Brad, S., B. Mocan, E. Brad, and M. Fulea. 2016. 'Environmentally Sustainable Economic Growth.' Amfiteatru Economic 18 (42): 446-6o.

Bueno, E., M. P. Salmador, and O. Rodríguez. 2007. 'The Role of Social Capital in Today's Economy: Empirical Evidence and Proposal of a New Model of Intellectual Capital.' Journal of Intellectual Capital 5 (4): 55674.

Commission of European Communities. 1994. 'On Immigration and Asylum Policies.' сом(94) 23 final, Commission of European Communities, Brussels.

Eberhard, C. 2008. 'Rediscovering Education through Intercultural Dialogue.' Paper presented at the International Meeting of Experts Cultural Diversity and Education UNESCO/UnEsC O Cat, Barcelona, 14-16 January.

Elliott, J. A. 2013. An Introduction to Sustainable Development. London: Routledge.

European Commission. 2001. 'Green Paper: Promoting a European framework for Corporate Social Responsibility'. Commission of the European Communities, Brussels. 
- 2008. 'Council Conclusions of 22 May 2008 on Intercultural Competences.' Official Journal of the European Union C 141/14-16.

- 2009. 'Sustainability Report.' Commission of the European Communities, Brussels.

- 2011. 'A Renewed EU strategy 2011-14 for Corporate Social Responsibility.' $\operatorname{Cом(2011)~} 681$ final, European Commission, Brussels.

- 2012. 'Green Paper: Unlocking the Potential of Cultural and Creative Industries.' http://ec.europa.eu/culture/our -policy-development/doc/GreenPaper_creative_industries_en.pdf

Fantini, A. 2007. 'Exploring Intercultural Competence: Developing, Measuring, and Monitoring.' Research Report 07-01, Washington University, St. Louis, MI.

Frantzeskaki, N., D. Loorbach, and J. Meadowcroft. 2012. 'Governing Societal Transitions to Sustainability'. International Journal of Sustainable Development 15 (1-2): 19-36.

Galletta, A., and W. E. Cross. 2013. Mastering the Semi-Structured Interview and Beyond: From Research Design to Analysis and Publication. New York: New York University Press.

Hasna, A. M. 2007. 'Dimensions of Sustainability'. Journal of Engineering for Sustainable Development: Energy, Environment, and Health 2 (1): 47-57.

Hawkes, J. 2001. The Fourth Pillar of Sustainability: Culture's Essential Role in Public Planning. Melbourne: Cultural Development Network.

Human Rights Council. 2007. 'Promotion of the Enjoyment of the Cultural Rights of Everyone and Respect for Cultural Diversity.' Resolution 6/6. https://ap.ohchr.org/documents/E/HRC/resolutions/A_HRC_RES_6 -6.pdf

Huntington, S. P. 1993. 'The Clash of Civilizations?' Foreign Affairs 72 (3): 22-49.

Joyce, N., L. Vincze, and E. J. Marton. 2016. 'Crossing the Communication Divide: Intergroup Contact and the Desire to Learn the Outgroup's Language.' Journal of International and Intercultural Communication 9 (4): 295-311.

Kates, R. W., T. M. Parris, and A. A. Leserowitz. 2005. 'What is Sustainable Development? Goals, Indicators, Values and Practice.' Environment: Science and Policy for Sustainable Development 47 (3): 8-21.

Kearns, A., and E. Whitley. 2015. 'Getting There? The Effects of Functional Factors, Time and Place on the Social Integration of Migrants.' Journal of Ethnic and Migration Studies 41 (13): 2105-29.

Kordestani, A., K. Peighambari, and T. Foster. 2015. 'Emerging Trends in Sustainability Research: A Look Back as We Begin to Look Forward.' International Journal of Sustainable Development 14 (2): 154-69. 
Larsen, C. A. 2014. Social Cohesion: Definition, Measurement and Developments. Aalborg: Aalborg University.

Lee, N. A. 2016. Sustainable Development and Complexity Science. N.p.: Amazon Digital Services.

Li, R. Y. M., and D. H. A. Pak. 2010. 'Resistance and Motivation to Share Sustainable Development by Web 2.o.' Journal of Information \& Knowledge Management 9 (3): 251-62.

Makarov, P. 2010. 'Intellectual Capital as an Indicator of a Sustainable Development.' Journal of Sustainable Development 3 (3): 85-9o.

Marrion, C. E. 2016. 'More Effectively Addressing Fire/Disaster Challenges to Protect Our Cultural Heritage.' Journal of Cultural Heritage 20 (7-8): 746-49.

Mulunga, S. N., and R. Yazdanifard. 2014. 'Review of Social Inclusion, Social Cohesion and Social Capital in Modern Organization.' Global Journal of Management and Business Research: Administration and Management 14 (3): 14-20.

oECD. 2011. Divided We Stand: Why Inequality Keeps Rising. Paris: Organization for Economic Cooperation and Development.

Sachs, J. 2015. The Age of Sustainable Development. New York: Columbia University Press.

Sage, D. 2013. 'Are More Equal Societies the Most Cohesive?' International Journal of Sociology and Social Policy 33 (11-12): 640-57.

Savitz, A. W. 2014. The Triple Bottom Line. San Francisco, C A: Jossey Bass.

Schoefthaler, T. 2006. 'Challenges in Assuring Dialogue between Cultures.' Presented at the forum Europe in Dialogue and Interaction between Cultures, Helsinki, 5 April.

Segalas, J., D. Ferrer-Balas, M. Svanstrom, U. Lundqvist, and K. F. Mulder. 2009. 'What Has To Be Learnt for Sustainability? A Comparison of Bachelor Engineering Education Competences at Three European Universities.' Sustainability Science 4 (1): 17-27.

Shaharir, B. M. Z. 2012. 'A New Paradigm of Sustainability'. Journal of Sustainable Development 5 (1): 91-99.

Singer, M. 2010. 'Eco-Nomics: Are the Planet-Unfriendly Features of Capitalism Barriers to Sustainability?' Sustainability 2 (1): 127-44.

Støvring, K. 2012. 'The Cultural Prerequisites of Social Cohesion: With Special Attention to the Nation of Denmark.' International Journal of Sociology and Social Policy 32 (3-4): 134-52.

Throsby, D. 1999. 'Cultural Capital.' Journal of Cultural Economics 23 (1-2): 3-12.

- 2001. Economics and Culture. Cambridge: Cambridge University Press. 
Tylor, E. 1871. Primitive Culture: Research into the Development of Mythology, Philosophy, Religion, Art, and Custum. London: Murray.

Ucok-Sayrak, O. 2016. 'Attending to the "Face of the Other" in Intercultural Communication: Thinking and Talking about Difference, Identity, and Ethics.' Journal of International and Intercultural Communication 9 (2): 122-39.

UnesCo. 1998. 'Intergovernmental Conference on Cultural Policies for Development.' https://unesdoc.unesco.org/ark:/48223/pfoooo113935

—. 2001. 'Universal Declaration on Cultural Diversity'. http://www .unesco.org/new/fileadmin/MULTIMEDIA/HQ/CLT/pdf/5_Cultural _Diversity_EN.pdf

- 2005. 'Convention on the Protection and Promotion of the Diversity of Cultural Expressions.' http://www.unesco.org/new/en/culture/ themes/culturaldiversity/diversity-of-cultural-expressions/the -convention/convention-text/.

- 2010. Resolution A/65/438 and Resolution 66/208. Culture and Development. http://www.cultura21.net/wp-content/uploads/2012/o6/ UNGA-66-208-EN.pdf

- 2013. 'The Hangzou Declaration. Placing Culture at the Heart of Sustainable Development Policies.' http://www.unesco.org/new/ fileadmin/MULTIMEDIA/HQ/CLT/images/

FinalHangzhouDeclaration20130517.pdf

United Nations. 2012. Resolution adopted by the General Assembly on 27 July 2012 (A/66/L.56)] 66/288. https://www.un.org/en/development/ desa/population/migration/generalassembly/docs/globalcompact/A _RES_66_288.pdf

United Nations World Commission on Environment and Development. 1987. Our Common Future. Oxford: Oxford University Press.

Utting, P. 200o. Business Responsibility for Sustainable Development. Geneva: United Nations Research Institute for Social Development.

Wells, J. C., and L. Lixinski. 2016. 'Heritage Values and Legal Rules: Identification and Treatment of the Historic Environment via an Adaptive Regulatory Framework.' Journal of Cultural Heritage Management and Sustainable Development 6 (3): 345-64.

Yarbrough, D. 2011. 'Interfaith Dialogue in the Pulpit - Proclaiming an Emerging Gospel.' Journal of Interreligious Studies 6:15-19.

Yencken, D., and D. Wilkinson. 2000. Resetting the Compass: Australia's Journey towards Sustainability. Collingwood: csiro Publishing. Yin, R. 1984. Case Study Research. Beverly Hills, CA: Sage. 



\title{
Influencer Marketing as a Modern \\ Phenomenon in Reputation Management
}

\author{
Josef Vodák \\ University of Žilina, Slovakia \\ josef.vodak@fri.uniza.sk \\ Martin Novysedlák \\ University of Economics in Bratislava, Slovakia \\ martin.novysedlak@euba.sk \\ Lucia Čakanová \\ University of Economics in Bratislava, Slovakia \\ lucia.cakanova@euba.sk \\ Miroslav Pekár \\ University of Economics in Bratislava, Slovakia \\ miroslav.pekar@euba.sk
}

The aim of the paper is to familiarize with the latest trends in the field of marketing communication. We can assume that the use of new forms of promotion is growing through the social media, leading to the challenge of competing for consumer attention. The evolving influencers community has significant power over brand and company perception, therefore it can largely affect its reputation. These new capabilities require communications professionals who strive for continuous collaboration with target customers through the various social web channels.

Key Words: influencer marketing, social media, reputation

JEL Classification: M31, M37

https://doi.org/10.26493/1854-6935.17.211-220

\section{Introduction}

Literature dealing with this issue provides a large number of definitions of influencer marketing. It is most often characterized as one of the most important new approaches in marketing in the last decade. The word 'influence' is generally defined as the force of impact on a person, thing, or event (Brown and Hayes 2008). It was found out that 90\% of customers trust the link from their personal network, with $81 \%$ of them trusting online recommendation (Biaudet 2017). With the huge number of social interactions that occur daily, companies are beginning to understand that customers express their opinions online and have the ability to change 
opinions of others (Pang and Lee 2008). As Groenewald says, brands have realized that the greatest success is achieved when satisfied customers tell their story of the brand (Groenewald 2018).

\section{CHARACTERISTICS OF BASIC TERMS}

Carter describes influencer marketing as a rapidly expanding industry, which is meant to promote products or increase popularity through content by influencers, i.e. social media users who are considered to be influential. As said by Krasniak (2016), the most important platforms on which influencer marketing is conducted are:

1. Instagram (used by $89 \%$ of sellers who use influencer marketing)

2. Facebook and Twitter (both are used by $70 \%$ of sellers)

3. YouTube $(59 \%)$

4. Blogs (48\%)

5. Snapchat $(45 \%)$

Influencer marketing, when properly implemented, is being used for a two-way communication opportunity that is a secondary strategy for social media to match authentic conversation with marketing messages (Centaur Communications 2017).

Cialdini (2006) describes that the process of influencing uses six principles of persuasion, including: consistency, reciprocation, social proof, authority, liking, and scarcity. These principles rely on the psychology of people who look beyond themselves when taking automatic decisions.

Influencer marketing as a phenomenon is a truly incredible equalizer and shifts the balance from power to any part of a subject that has the ability to share something. Social media are also introducing new opportunities for companies to connect with people, but people can also connect with others. The goal is to join new communities and link a brand or product with a new audience through a trusted relationship with that influencer.

For example, the Maybelline brand, which has its own YouTube channel, will reach approximately 20,000-30,000 views for each video. It's not bad, but the video generated by influencer has an average of 1.4 million views. This is a clear sign that influencers are raising more interest in Maybelline products than their own brand channel. Influencers in fact represent Maybelline brand to new consumers much better than the brand does on its own (Tapinfluence 2017). 
Influencer marketing also often involves working with influence agencies. Niche, Socialyte, Viral Nation, The Amplify, Izea and Mediakix are some of the agencies in this marketing space. Some of them are specific to individual platforms, such as Instagram marketing, while others have a broad portfolio of influencers. These agencies do not merely associate influencers with sellers or their advertising markets, but they also help individuals to become successful influencers.

Established in 2002 in Paris, Augure helps over 1,500 brands and agencies of all sizes (including Nestlé, Renault-Nissan, L'Oreal) to bridge the gap between PR and influencer marketing. Thus, through Augure, professionals can engage key strategies to raise awareness, build trust and relationships between brand and customer.

Augure $^{* \star \star}$ has released a 'Marketing Status Report 2014,' with nearly 650 marketing and communications experts attending the survey, according to which:

- $73 \%$ of companies surveyed said they started working with influencers to improve marketing strategies 2 years ago or even longer in many cases,

- $69 \%$ of companies have confirmed that cooperation with influencers has paid off, has been effective and has led to the expected results,

- $44 \%$ of companies and agencies said that influencers play a key role in creating a marketing strategy.

The report of Gulberti (2014) also revealed that marketing and communication agencies face several challenges:

- Identify relevant influencers for their specific brands and requirements $(61 \%)$.

- Be able to capture the attention of the followers and maintain their interest (56\%).

- Measure and accurately assess the return on investment (44\%).

\section{Social Media as a New Form of Marketing Communication}

Companies are heading to attract customers through influencers, especially because of the ability to block ads, they want to be able to distribute without being blocked and reach the right audience. The content of the influencer cannot be blocked and the best method of gaining customer trust is through whom the customers already believe. Creating such an intimate relationship between the customer and the influencer is almost impossible for the brand itself (Hall 2016). 

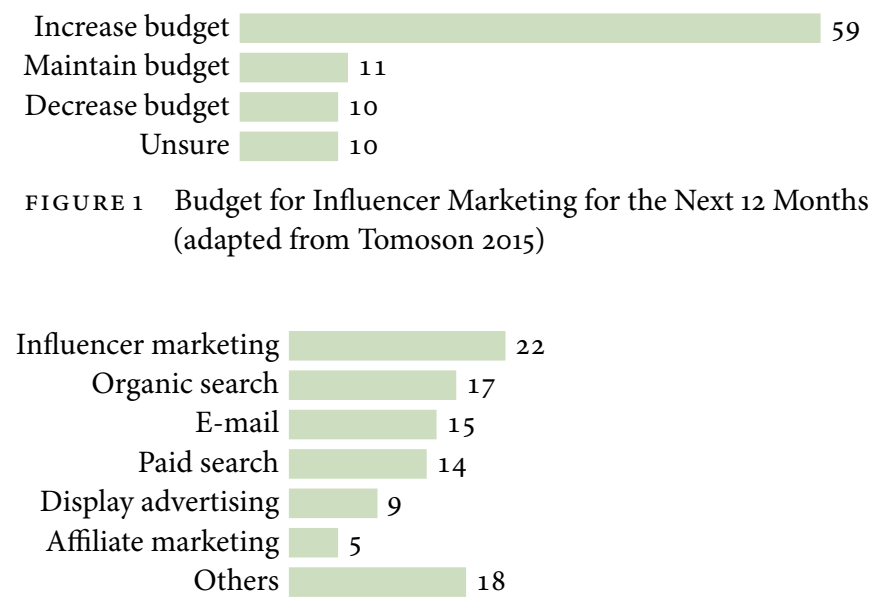

FIgURE 2 The Fastest Growing Online Customer Acquisition Method (adapted from Tomoson 2015)

According to a study by startup companies TapInfluence and Influitive, customers believe the recommendation through their own network up to $90 \%$, and to online recommendations in $81 \%$ of cases. People believe recommendations from people they know in over 92\% (Tapinfluence 2017).

In 2015, Tomoson Company conducted research and summarized the information received from the 125 participating top businesses. Based on research of influencer marketing, stores earn $\$ 6.50$ over every $\$ 1$ spent on influencer marketing. The research involved 125 online sellers during 10-16 March 2015 (Tomoson 2015).

It has also been shown that most of $59 \%$ of businesses plans to increase their influencer marketing budget over the next twelve months. On the other hand, $21 \%$ are planning to reduce or keep the same for influencer marketing.

Influencer marketing has also been rated as the fastest growing online channel for customers. Organic search was ranked second with $17 \%$, followed by email with $15 \%$.

In research where companies responded to a question which the most cost-effective channel for online customer acquisition is, influencer marketing, along with email, came first. They both reached $22 \%$ of the votes.

When asked about the quality of influencer customers, $51 \%$ of traders believe they can get better customers with influencer marketing.

According to the Instagram website, $75 \%$ of instagrammers (Instagram users) act after they have been inspired by a post and $60 \%$ of instagram- 


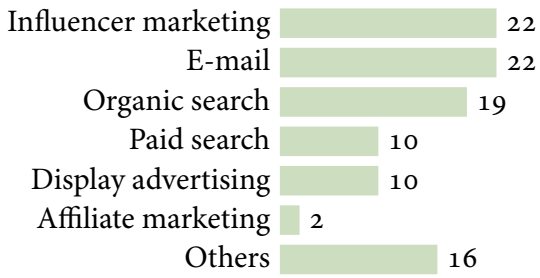

FIgURE 3 The Most Cost-Effective Method of Online Customer Acquisition (adapted from Tomoson 2015)

mers claim to have discovered new products through Instagram. Speaking of influencer marketing, Instagram was the most powerful social action channel in 2015, reaching a social share value of $3.21 \%$ compared to $1.5 \%$ of all other RythmOne's Influencer Marketing Benchmarks Reports in 2015 (RythmOne 2016).

Based on Annalect marketing research conducted by 2017 on Instagram influencer marketing in Finland, $73 \%$ of Finnish Instagram users follow the Instagram of influencers, bloggers, celebrities, and content moderators profiles. Interests of influencers and their tips for different products are generally considered by customers to be useful. The studies also show that Instagram resonates mainly in the younger age category and they are the most likely to buy a product or service based on the recommendation of Instagram influencers. According to the same study, up to one third of those influenced by influencer marketing made an investment decision based on influencer marketing.

Influencer marketing can be considered a form of product placement because it involves deliberately including brand messages in editorial media content. Although product placement was originally developed in 2006 in the context of traditional media such as books, movies or $\mathrm{TV}$ shows, this practice has recently expanded into social media in the form of influencer marketing. According to Russel and Stern (2006), product placement has been found to improve:

- remembering brands,

- increases brand access and brand selection,

- increases purchasing intentions,

- allows the product to be presented in consumption situations, to which viewers can project themselves.

In the context of social media, product placement can be particularly persuasive, because followers tend to develop a sense of friendship 
with the influencers they admire, although often unilaterally. This phenomenon is also called 'parasocial interaction.' Such followers believe influencers and are willing to replicate their behaviour and appropriate their product selection. Despite its effectiveness, product placement is sometimes criticized because it is based on a promotional intention that can be unclear to consumers (Boerman, Willemsen, and Van Der Aa 2017).

In marketing, support plays an important role in achieving a company's good reputation and business goals. In recent years, social media influencers have influenced potential customers by creating a range of fashion words compared to other marketing strategies (e.g., celebrity support) that are considered to be the most cost-effective and effective marketing trends (Harrison 2017). Moreover, social media influencers can present a convincing outcome, both in the media and in consumer beliefs (Booth and Matic 2011).

Based on influencer marketing principles, the company receives social media influencers such as bloggers with thousands of followers on social media accounts as their brand ambassador (Tapinfluence 2017). Messages spread by influencers of social media are often perceived as more reliable and more convincing to consumers and justified. $82 \%$ of customers say consumers follow the recommendations of their favourite influencers (Talaverna 2015).

Compared to the promotion strategy for celebrities, the use of social media influencers is considered to be more credible through the establishment of friendly relationships with consumers, especially for younger generations (Berger 2017). Furthermore, in the literature, we can often meet with advertising of the product spread in the form of spoken or written communication between existing and potential customers, so-called 'word of mouth.' This can be better freely understood as 'personal recommendation' or 'what is being generally discussed about' (Lim and Cheung 2014).

According to Brown and Fiorella, the customer should be at the centre of influencer marketing efforts and companies can build their profile in what cycle they are currently in. It can be in a research phase where they collect information, or in an awareness-raising phase, where they need validation from people they know, or they can be in the purchasing phase where they make the necessary investments. Since each phase presents the need for other tactics, society needs to identify where it is and to contact people and 'make' them influencers who move people into 


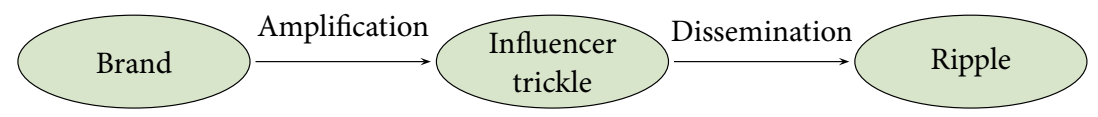

FIGURE 4 Trickle Stage and Ripple Stage of Influencer Marketing (adapted from Brown and Fiorella 2013)

the purchasing decision phase. In this way it is possible to get directly to the customer via the right influencer at the right time.

According to Brown and Fiorella (2013), there are two main stages in each influence campaign - 'trickle and ripple phase' which means the stage of launching and the wave stage. The message is distributed when it is launched and its direction determines whether the campaign will be successful or not. The path of the message is not simple and only passed to influencer because social media noise can cause many unsuccessful attempts. In order to successfully overcome this stage, companies, together with influencers, need to identify key tracker information about their followers:

- The time when they are most often online.

- Platforms on which they are located.

- People with whom they will communicate.

- Topics about which they will communicate.

- Activities they will be performing.

If the influencers are already segmented and segregate which of the communities will be able to respond to the message, the potential of influencer marketing is shifting from possible to probable. Thus, if a company's success is likely, it goes from the trickle phase to the ripple phase. At this stage, the influencer community is already noticing brand message. Here, the followers are spreading the message within their community and creating a wave of brand awareness and various graduated news.

\section{Conclusion}

In the age of the ubiquitous Internet, influencers are a new type of independent third party that shapes audience attitudes through blogs, tweets, and other social media (Freberg et al. 2011). Through activities that include expressing their opinions, for example, in product reviews, through tips and tricks videos, to organizing competitions and posting images containing products or services (Bernitter, Verlegh, and Smit 2016). 
Utilizing a wide range of social media platforms such as Facebook, Instagram, Twitter and YouTube, social media influencers are well suited to publish product information and the latest promotions for online followers (Influencer marketing vs word-of-mouth marketing Markethub 2016).

According to Kaplan and Haenlein (2010), influencers publish their posts on different platforms to express:

- their opinions (e.g. TripAdvisor, Amazon);

- inform about their network (e.g. Twitter);

- share their expertise (e.g. Wikipedia);

- express their passions (e.g. personal blogs, Instagram, Pinterest, Facebook).

Influencers thus gain enhanced competencies in creating sophisticated content, form stories, videos and visuals. Given the scalability of the Internet and the speed of dissemination, these influencers can quickly attract mass audiences and achieve 'fame' through the accumulation of cultural capital (McQuarie, Miller, and Phillips 2013).

\section{Acknowledgments}

This paper was supported by Slovak Research and Development Agency under contract APVV-15-0511.

\section{References}

Annalect Research. 2017. 'Instagram Influencer Marketing in Finland.' https://www.annalect.fi/research-instagram-influencermarketing -finland/.

Berger, J. 2017. Invisible Influence: The Hidden Forces that Shape Behavior. London: Simon \& Schuster.

Bernitter, S., P. W. J. Verlegh, and E. G. Smit. 2016. 'Why Nonprofits Are Easier to Endorse on Social Media: The Roles of Warmth and Brand Symbolism.' Journal of Interactive Marketing 33:27-42.

Biaudet, S. 2017. 'Influencer Marketing as a Marketing Tool.' https://www .theseus.fi/bitstream/handle/10024/134139/Biaudet_Sofie.pdf ? sequence $=1$ \&isAllowed $=y 7$

Boerman, S., L. M. Willemsen, and E. P. Van Der Aa. 2017. “This post is sponsored": Effects of Sponsorship Disclosure on Persuasion Knowledge and Electronic Word of Mouth in the Context of Facebook. Journal of Interactive Marketing 38:82-92. 
Booth, N., and J. A. Matic. 2011. 'Mapping and Leveraging Influencers in Social Media to Shape Corporate Brand Perceptions.' Corporate Communications: An International Journal 16 (3): 184-91.

Brown, D., and S. Fiorella. 2013. Influence Marketing: How to Create, Manage, and Measure Brand Influencers in Social Media Marketing. Indianapolis, IN: Que Publishing.

Brown, D., and N. Hayes. 2008. Influencer Marketing: Who Really Influences Your Customers? Amsterdam, Boston: Elsevier.

Centaur Communications. 2017. 'Influencer Marketing: Mobilise the People to Shape Your Brand.' https:/www.marketingweek.com/2010/ 02/02/mobilise-the-people-to-shape-yourbrand/

Cialdini, R. B. 2006. The Psychology of Persuasion. Sydney: HarperCollins Australia.

Freberg, K., K. Graham, K. McGaughey, and L. A. Freberg. 2011. 'Who Are the Social Media Influencers? A Study of Public Perceptions of Personality.' Public Relations Review 37 (1): 90-92.

Groenewald, P. 2018. 'The Rise and Rise of Influencer Marketing.' http:// www.thesalt.co.za/rise-and-rise-of-influencer-marketing/.

Gulberti, G. 2014. 'BusinessWire.' https://www.businesswire.com/news/ home/20140227005788/en/6o-Marketing-Communication -Professionals-Investing-Influencer-Marketing\#.U1T7TaLzfvo

Hall, J. 2016. 'The Influencer Marketing Gold Rush Is Coming: Are You Prepared?' http://www.forbes.com/sites/johnhall/2016/o4/17/the -influencer-marketing-gold-rushiscoming-are-you-prepared/ \#26a8fo5f2964

Harrison, K. 2017. 'Top 10 Trends that Will Transform Digital Marketing in 2017.' https:/www.forbes.com/sites/kateharrison/2017/o1/o9/top -1otrendsthat-will-transform-digital-marketing-in-2017/ \#7e6d507d3bf5

Kaplan, A., and M. Haenlein. 2010. 'Users of the World, Unite! The Challenges and Opportunities of Social Media.' Business Horizons 53 (1): 5968.

Krasniak, M. 2016. 'Social Influencer Marketing on the Rise: New Research.' http://www.socialmediaexaminer.com/social-influencer -marketing-on-therise-new-research/

Lim, B. Ch., and Ch. Cheung. 2014. 'Word-of-Mouth: The Use of Source Expertise in the Evaluation of Familiar and Unfamiliar Brands.' Asia Pacific Journal of Marketing and Logistics 26 (1): 39-53.

Markethub. 2016. 'Influencer Marketing vs Word-of-Mouth Marketing.' https://www.markethub.io/influencer-marketing-vs-word-of-mouthmarketing/.

McQuarie, E. F., J. Miller, and B. J. Phillips. 2013. 'The Megaphone Effect: 
Taste and Audience in Fashion Blogging.' Journal of Consumer Research 40 (1): 136-58.

Pang, B., and L. Lee. 2008. 'Opinion Mining and Sentiment Analysis.' Foundations and Trends in Information Retrieval 2 (1-2): 1-135.

Russel, C., and B. Stern. 2006. 'Consumers, Characters, and Products: A Balance Model of Sitcom Product Placement Effects.' Journal of Advertising 35 (1): 7-21.

RythmOne. 2016. 'Influencer Marketing Benchmarks Report of 2015.' https://www.rhythmone.com/assets/insights/RhythmOne_Full_Year _2015_Influencer_Marketing_Benchmarks_Report_rev1.pdf

Talaverna, M. 2015. '10 Reasons Why Influencer Marketing Is the Next Big Thing.' https://www.adweek.com/digital/10-reasons-why-influencermarketing-is-the-next-big-thing

Tapinfluence. 2017. 'What Is Influencer Marketing?' https://www .tapinfluence.com/blog-what-is-influencer-marketing

Tomoson. 2015. 'Influencer Marketing Study.' http://blog.tomoson.com/ influencer-marketing-study

This paper is published under the terms of the Attribution-

NonCommercial-NoDerivatives 4.o International (CC B Y-NC-ND 4.0)

License (http://creativecommons.org/licenses/by-nc-nd/4.o/). 


\title{
Drivers that Impact the Merchants' Repeat Intention for Group Deal Promotions
}

\author{
Nina Angelovska \\ Macedonian E-commerce Association, North Macedonia \\ nina.angelovska@gmail.com \\ Sasho Josimovski \\ University 'Ss. Cyril and Methodius,' North Macedonia \\ saso.josimovski@eccf.ukim.edu \\ Lidija Pulevska Ivanovska \\ University 'Ss. Cyril and Methodius,' North Macedonia \\ lidija.pulevska@eccf.ukim.edu
}

\begin{abstract}
The purpose of this study is to investigate the drivers affecting merchant's intention to repeat group deal offers and use the group buying site as a promotional tool. The research is done based on secondary and primary data collection. Primary data was collected through a questionnaire aimed at businesses that had completed a daily deal promotion. Tobit model was employed to analyze data. The results show that merchants' intention to repeat offers depends on profitability of the deals output, spending beyond the coupon, new customers brought by the deal, and there is diversity across different categories of businesses. Findings of this study can be useful to group buying companies to improve their business to small- and medium-sized businesses considering a daily deal promotion.
\end{abstract}

Key Words: retailers, profitability, marketing, tobit model, group buying model, promotions, Macedonia

JEL Classification: M31, M21

https://doi.org/10.26493/1854-6935.17.221-238

\section{Introduction}

The advent of electronic commerce has led to the creation of many new business models for Internet-based selling (Kauffman and Wang 2001). The Web has enjoyed tremendous growth in consumer spending as a channel that is characterized by convenience, wide product selection, and easy comparison shopping (Kauffman and Wang 2002). The business model of group buying was introduced by the company Groupon in 2008. It represents a win-win for both the retailers and end-customers; savings for the end-customers and new customers for the retailers. As the group 
buying sites are intermediaries between retailers and final users, they have to focus twofold: to the retailers and the end-users. As two-sided markets, daily-deal platforms allow merchants to attract new consumers via discounts (Subramanian and Rao 2016). Retailers are the core of the group deal sites business model because they produce the product that the site markets. Acquiring more retailers diversifies the list of products they can market, which allows them to attract more paying subscribers and increase revenues. However, what is more important than the acquisition of featured retailers is the retention thereof, or their intention to repeat deal offers. The acquisition growth will undoubtedly slow, as there can only be a finite number of retailers willing to use the service, especially in the small emerging countries. Consequently, the majority of revenues must come from repeat retailers.

The model was so successful and enjoyed massive growth in 2010 and is growing rapidly in emerging economies (Erdogmus and Cicek 2011). Hundreds of daily deal sites have been launched. As an online promotion form, group-buying model has low barriers to entry therefore it can be quickly launched but evidence show that it can be as quickly closed due to fierce competition. A significant number of launched group buying sites shut down, merged with other sites, or changed their business models drastically (Taulli 2012; Heussner 2012; Reisinger 2011; Geron 2011).

The CEO of Groupon India, Ankur Warikoo, claims that the lack of focus on the merchants is the main reason for this (TechCircle 2013). Despite these upheavals, however, the industry's market leaders have remained unchanged and continued to grow impressively. For instance, Groupon acknowledged that merchant retention was integral to revenue growth and achieving profitability (Mazen 2012). It is often difficult and impossible, for small and medium sized enterprises, to place properly their products in customers' minds due to the shortage of capital and resources (Gilmore and Grant 2001).

Many challenges are posed to the new promising model of group buying via daily deals, thus there is need to understand what affects the merchant's decision when evaluating its deal effectiveness and decision to repeat the promotion. With this overall concern in mind, this paper examines the dependency of merchant's deal repeat intention across several factors including new customers acquired from the deal; customer's spending beyond coupon face value and repeat customers and company characteristics as well.

The remainder of this paper is organized as follows. Review of the re- 
lated literature is presented in the second section. In the third section summary of Grouper.mk and its market position is given. The fourth section presents the methodology of the survey and data collection and analysis. In the fifth section, the results are analyzed. The sixth section states the limitations of this research and finally the seventh section concludes and discusses the issue of sustainability of the deal sites promotion on long term and provide specific suggestions for the deal sites for creating the offers that will satisfy the drivers for repeat offers.

\section{Literature Review}

Beyond the academic work on voucher discounts, a well-established literature explores the advertising and pricing of experience goods, i.e. goods for which some characteristics cannot be observed prior to consumption (Nelson 1970; 1974). A substantial literature has observed that selective discounting provides opportunities for price discrimination. For example, in the setting of Varian (1980), firms engage in promotional pricing in order to attract larger market segments. Similar work illustrates how promotions may draw new customers (Blattberg and Neslin 1990), and lead those customers to become relational customers (Dholakia 2006). These results have been found to motivate the use of coupons, especially cents-off coupons (Cremer 1984; Narasimhan 1984). Generous discounts generate more sales from group buying customers (Grandhi, Chugh, and Wibowo 2016). The online group buying act is characterized by the dual value creation philosophy of marketing (Kotler and Armstrong 2009) that both sellers and buyers benefit through it (Anand and Aron 2003). Benefits for buyers are more than obvious because on the group buying sites end customers gain great discounts (Stulec and Petljak 2010). Cao, Hui, and $\mathrm{Xu}$ (2018) found that the offering of discounts should be tied to consumers' confidence in product quality, meaning a one-size-fits-all strategy will not be optimal. The main category of the deal industry in the beginning was the services but soon the goods became very popular as well as the travel deals, imposing the categorization of the deals in 3 main categories: services, goods and travel. Group buying websites' customers are computer literate persons, mostly younger aged who do not have an aversion towards electronic commerce and are mostly members of social networks (Stulec, Petljak, and Vouk 2011).

Benefits for sellers are harder to define unambiguously because they are not exclusively of a financial nature. First, it is important to mention that the group buying websites are an excellent way of promotion 
(Stulec and Petljak 2010). Furthermore, this form of promotion allows companies to reach new customer segments that are more likely to notice an advertisement on a computer screen than in printed form because of their lifestyle (Stulec and Petljak 2010). Benefits are especially great for small businesses that cannot afford advertising through mass media, so group-buying websites can be seen as an excellent way of familiarizing potential customers with products and services of small businesses (Stulec and Petljak 2010). Understanding group buying as an innovative market niche, small and medium enterprises (SMEs) make an attempt to cooperate with particular buying services looking for their sources of competitive advantage in this way (Bilinska-Reformat and Reformat 2011).

The claims and frequent comments about group buying and local deal sites such as Groupon having lost their appeal and are unsustainable were mostly toward its effectiveness for the merchants (Bazilian 2011; Guy 2012; Kamenec 2012; Li, 2012). Groupon's previously reported waiting list of 35,000 businesses suggests that many businesses are eager to experience the value of group buying deals (Sherr 2010); however, group buying deals are not a guarantee of success for small businesses. Articles in the popular press and elsewhere have questioned the value for small businesses, pointing out that the costs of offering some deals cannot be covered by the revenue from deals sold (Vacanti 2011). To give answers to these claims literature has provided empirical evidence on the impact and structure of voucher discounting, measuring merchants' uses of vouchers and consumers' responses. Dholakia (2010) surveys businesses that offered Groupon discounts, finding that some business owners speak glowingly of Groupon, while others regret their voucher promotions. Byers, Mitzenmacher, and Zervas (2012) study the dynamics of discount voucher sales as well as the impact of voucher coupon use on Yelp ratings. Gupta et al. (2012) present complementary findings based on survey evidence, characterizing the types of merchants most likely to profit from offering vouchers.

Groupon has claimed that $97 \%$ of businesses using its service want to be featured again. But an independent study estimates repeat intent at only $48 \%$ (Dholakia 2010). For many small and medium-sized businesses, particularly for ones that are new or struggling, hordes of new customers flocking in because of a social promotion may seem particularly appealing during times when consumers have cut back on so many products and services (Dong-Hun 2009; Kotecha, Leibowitz, and MacKenzie 2008). 
Some prior research also supports the effectiveness of price promotions in drawing new customers to businesses (Walters and MacKenzie 2008). Furthermore, as Greenleaf (1995) has observed, one powerful reason that firms use price promotions is that they can increase profits.

\section{Grouper Summary}

In Macedonia, group-buying websites emerged in 2011 and Grouper was the first one launched in January. Online group buying quickly became a bright spot in the mainland of e-commerce market. It nurtured a group of online shoppers and speeded up the development of the e-commerce market in Macedonia. Grouper is not just the first online group buying site on the Macedonian market, but is leader in the e-commerce industry holding 40\% of the market share in Republic of Macedonia in 2012 and 2013 (see http://www.grouponworks.com). The development of the industry is similar as the global trends mentioned above; many group deal sites opened and many of them have shut down after one year of operation.

By this time, a significant number of local businesses have tried running daily deal promotions, and many of them have run multiple ones.

Over the years Grouper kept its leading position by focusing both on merchants and end-customers. The number of customers has grown over the years and amounts 95.000 in 2014.

The number of new merchants per month, as well as the published deals is in progression since the launch of Grouper. While the number of deals published increases with tremendous rate over the years, the number of new merchants starting cooperation keeps a steady increase rate of about $35 \%$ per year (figure 1). The increase rate in the number of deals published amounts about $100 \%$ on yearly bases which indicates a high deal frequency by existing merchants.

\section{Methodology}

The research is done based on secondary and primary data collection. Internal database of group buying site Grouper, as a good starting point is analyzed, particularly the number of featured promotions each retailer offered. Grouper retailers' internal database is used to quantify the repetition rate. The data analyzed covered the period between January 2011 and July 2014. The number of new retailers by year, category and number of featured deals were examined. Out of total 1065 retailers that offered promotion at least once on Grouper in the period between January 2011 


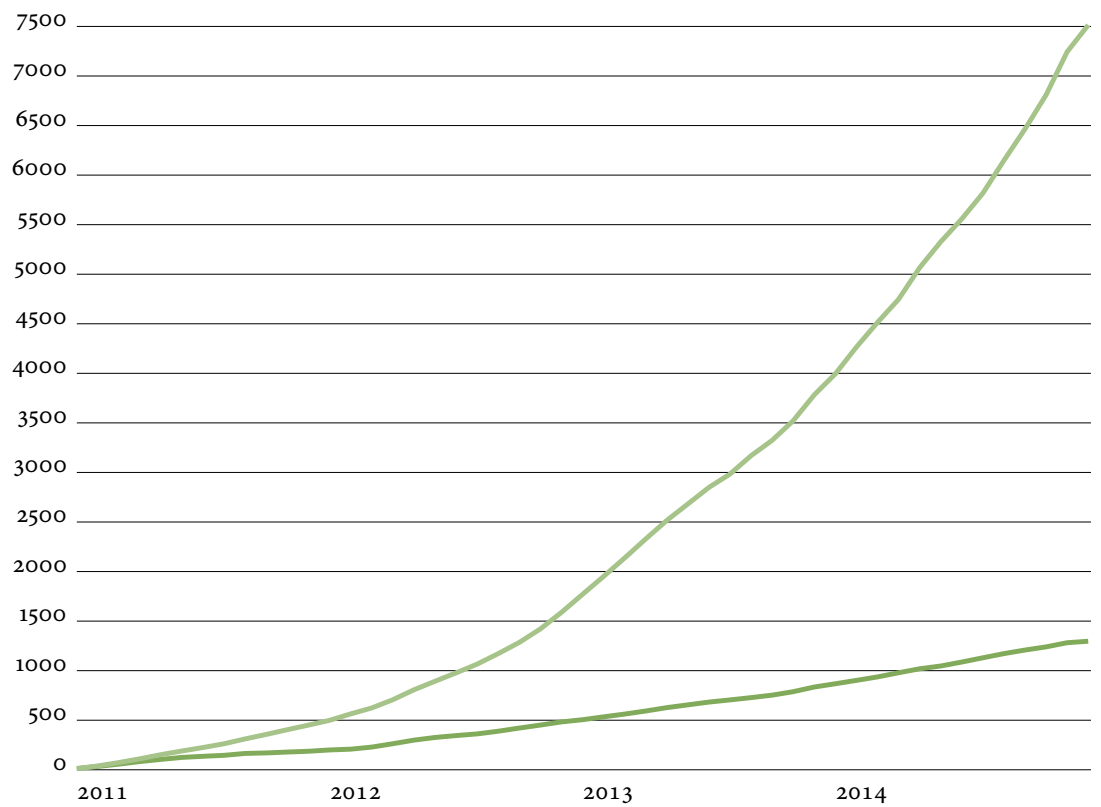

FIGURE 1 Grouper's Growth of Daily Deals Published and New Merchants (January 2011-January 2015)

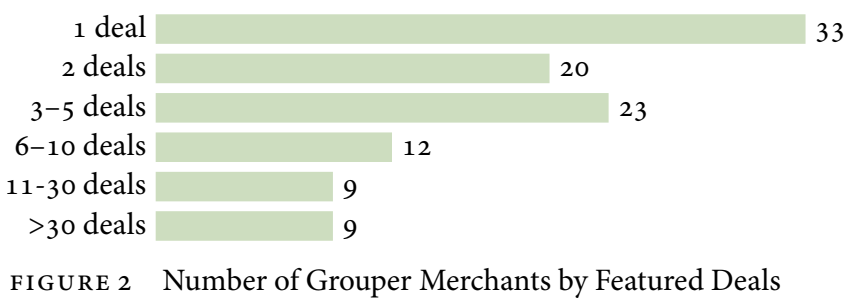

and July 2014, 60\% had promotions running more than once. However the number of retailers with only one deal promotion has to be corrected because of two reasons: (1) the number of retailers that closed their business and (2) the number of retailers that had their first promotion offered in the recent period, because of the short time period for being able to run a second promotion. Considering these corrections, $67 \%$ of retailers running Grouper promotions were repeat retailers (figure 2).

The industry that has the lowest repetition rate is Food and Drink. From 12 retailer's categories (food and drink, beauty, education, automobile, children, culture, sport and entertainment, health, travel, products and miscellaneous) restaurants and café bars account for $20 \%$ of the re- 
tailers that offered only one promotion. On the other hand two categories account for $70 \%$ of the retailers that offered over 30 deals. One is Products, which is logical because one company offered many different products at one time. The second category, which deserves more attention, that participates with $36 \%$ of the retailers with highest repetition rate is the Beauty, particularly Beauty Salons and Spas. These findings coincide with Dholakia (2010), who found that restaurants seemed to be disproportionate failures when it came to Groupon deals while spas were disproportionate winners.

Primary data were collected through an online field survey of businesses that had completed a daily deal promotion with Grouper in the period between January 2013 and June 2014. Aiming to quantify precisely the percentage of the repetition rate of the retailers, attention is given to the retailers that offered only one deal and the selection of the surveyed companies was done: (1) Companies that started cooperation and offered their first deal since May 2014 were extracted from the total number of retailers with one deal offered, because of the short time period for possible second deal; (2) The number of companies that shut down the business was taken out of the final number of retailers that cooperated only once.

The questionnaire was developed via pilot study: (1) A small group of four businesses that had recently run Grouper promotions are called and their owners interviewed to gain a qualitative understanding of their experience with the promotion. (2) The questionnaire was tested within the same group of companies and suggested comments were implemented.

The questionnaire was in Macedonian language and consisted of $3 \mathrm{sec}-$ tions. The first section was consisted of general demographic data for the company: field of operation, years of operation, size and previous promotional tools used; and general information for the Grouper promotional deal: number of featured deals, average regular price and\% of discount. The second and third sections were conditional and based on the answer of the last question of the first section. The retailer that featured deals only on Grouper replied to the further questions in the Section 2 and the retailer that offered promotions on other sites as well replied to the questions in Section 3. In Section 2 and 3 the retailers were asked questions about the particular deals they had run: How merchants value the performance of the offered deals to Grouper compared to other group buying sites measured in: profitability, number of new customers, returning customers from the deal promotion, how much customers' spend beyond face value and the redemption rate of the coupons. Each one is discussed 
in details below. If the retailer runs deals only via Grouper he got the questions for the particular Grouper deals and if he had cooperated with more deal sites he got the same questions except he had to reply answers in a grid comparing Grouper and the other site they were featured on.

An email to 535 grouper businesses partners was sent from the official Grouper contact mail.

Two weeks later, a second e-mail was sent to the companies thanking those who responded and reminding the rest to answer the questionnaire. The study was conducted for a period of three weeks in July. It was closed with 105 completed responses, resulting in response rate of around $20 \%$.

To analyze the collected data quantitative research methods are applied. Descriptive statistics is used to describe and compare the data. The determinants of whether to repeat offers or not are considered to be the identical and empirically, the tobit model was employed to estimate the factors that will drive merchant intention to repeat the deal offers or not. Thus, the decision-making process is considered to be dual where the dependent variable measures the probability of the merchant intention to repeat the offers on the group buying site. So the model is constructed to investigate: What are the drivers that will influence merchants' intention to repeat offers to group buying site? Three broad sets of factors influencing merchants 'repeat intention were considered as independent variables: deals output characteristics, firm characteristics, and deals characteristics. The hypotheses to be tested with the model are:

$\mathrm{H} 1$ Deals output characteristics impact the intention of the merchants to do repeat offers on the group buying site.

H1.1 Profitability impacts the intention of the merchants to do repeat offers on the group buying site.

$\mathrm{H} 1.2$ Repeat customers impact the intention of the merchants to do repeat offers on the group buying site.

H1.3 Spending beyond the coupon impacts the intention of the merchants to do repeat offers on the group buying site.

H1.4 New customers impact the intention of the merchants to do repeat offers on the group buying site.

H1.5 Nonredemption impacts the intention of the merchants to do repeat offers on the group buying site.

$\mathrm{H} 2$ Firms characteristics impact the intention of the merchants to do repeat offers on the group buying site. 
H 2.1 Number of employees impact the intention of the merchants to do repeat offers on the group buying site.

$\mathrm{H} 2.2$ Company category impacts the intention of the merchants to do repeat offers on the group buying site.

$\mathrm{H} 2.3$ Type of the promotion company does impacts the intention of the merchants to do repeat offers on the group buying site.

$\mathrm{H} 2.4$ Firm age impacts the intention of the merchants to do repeat offers on the group buying site.

$\mathrm{H} 3$ Deals characteristics impact the intention of the merchants to do repeat offers on the group buying site.

H3.1 Number of sold coupons impacts the intention of the merchants to do repeat offers on the group buying site.

H3.2 Discount of regular price impacts the intention of the merchants to do repeat offers on the group buying site.

Following Greene (2003), the general specification for the tobit specification is:

$$
\begin{aligned}
y_{i}^{*}= & x_{i}^{\prime} \beta+\sigma \varepsilon_{i} \\
y_{i}= & \begin{cases}0 & \text { if } y_{i}^{\star} \leq \mathrm{o} \\
y_{i}^{*} & \text { if } y_{i}^{*}>\mathrm{o}\end{cases} \\
& \varepsilon \sim N\left(\mathrm{o}, \sigma^{2}\right)
\end{aligned}
$$

where $y_{i}$ equals zero implies that the firm does not intent to repeat deals, while $y_{i}$ equals $y_{i}^{*}$ implies that the firm intents; $i=1,2, \ldots, N$ firms; $x_{i}$ denotes the $1 \times(k+1)$ vector of observed explanatory variables describing: Deals output characteristics; Firm characteristics and Offered deals characteristics. $\beta$ represents the corresponding $(k+1) \times 1$ vector of coefficients to be estimated; and $\varepsilon_{i}$ are the error terms that are independently and individually distributed (iid) over the whole sample with a mean of $\mathrm{o}$ and variance $\sigma^{2}$.

\section{Data Analysis and Results}

The analysis is based on a total of 105 responses of Grouper Merchants that offered deal between January 2013 and June 2014. Around 40\% of the responses are found to be in education and health category. Least responses are given by category Jewelry and Fashion. 
Participated companies are mostly small or half with 3-5 employees, and $13 \%$ over 20 employees. Over $50 \%$ of the participants are companies over 5 years existence and the other half is bellow. $85 \%$ of the participated companies have repetition rate, even $22 \%$ are with more than 10 deals. Considering the use of this new promotional tool, Macedonian companies participating in the survey use social media and group deal sites mostly (44\%), and least Radio and $\mathrm{TV}$.

According to responses $45 \%$ of the companies are loyal to Grouper, and $55 \%$ were running deals on other group buying sites.

The results of the estimated coefficients using equation (1) are presented in table 1 . Before the interpretation of empirical results, a brief discussion regarding diagnostic tests even though such tests are not welldeveloped for tobit model is provided. According to the pseudo $R^{2}$ measure of the overall fit, and the LR $\chi^{2}$ and Prob $>\chi^{2}$ measures of the joint and partial significance of the parameters the model estimations perform well. As shown in table 1, the results in the last column present the expected correlations of the independent variables with the dependent variable: merchants' intention to repeat offer.

Strong support in the model is found for the correlation between merchants' intention to repeat offers and characteristics of the output of deals redemption, namely the profitability of the deals output, followed by the spending beyond the coupon. Also positive correlation is found or it is important for the merchants is new customers brought to the business.

Statistically significant (at $1 \%$ significance level) support is found for H1.3. Spending beyond the coupon face value is useful in assessing a group deal promotion's success because it generates revenue for companies. Beside of getting new customers in the door, as the goal of the promotion the expectations are that they will spend beyond its coupons' value. Small and medium-sized businesses across a range of industries were asked to declare the percentage of customers that spend beyond the group deal's value. $45 \%$ of the participants running Grouper promotions reported o$10 \%$ of the customers spending beyond coupons' face value and $34 \%$ noted spending customers between $11-25 \%$. Table 2 shows percentage of spending beyond the deal promotion face value on Grouper and on the other group sites. $55 \%$ of the respondents running Grouper promotions had 10\% of the customers that spent beyond coupons' value vs. $39 \%$ on the other group sites.

As purpose of group buying promotions is to bring customers to doors of the company and encourage trial of a new product, or of an existing 
TABLE 1 The Estimated Determinants of Intention for Repeat Offers

\begin{tabular}{|c|c|c|c|c|}
\hline Category & Variables & Coeff. St & Std. error & Expected sign \\
\hline \multirow{5}{*}{$\begin{array}{l}\text { Deals output } \\
\text { characteristics }\end{array}$} & Profitability & $39.02^{*}$ & $(24.01)$ & Positive \\
\hline & Repeat customers & -1.22 & $(21.65)$ & Ambiguous \\
\hline & Spending beyond the coupon & $7.20^{\star * *}$ & * $(27.99)$ & Positive \\
\hline & New customers & $2.15^{\star *}$ & $(25.61)$ & Positive \\
\hline & Nonredemption & 0.01 & $-5,131$ & Ambiguous \\
\hline \multirow{4}{*}{$\begin{array}{l}\text { Firm } \\
\text { characteristics }\end{array}$} & Number of employees & -0.157 & $-6,665$ & Nonlinear \\
\hline & Company category & $40.66^{\star}$ & $(23.33)$ & Positive \\
\hline & Type of promotion firm does & -139.2 & $(90.55)$ & Ambiguous \\
\hline & Firm age & $-8,980$ & $(21.33)$ & Ambiguous \\
\hline \multirow{10}{*}{$\begin{array}{l}\text { Deals } \\
\text { characteristics }\end{array}$} & Number of sold coupons & 2,654 & $(18.17)$ & Positive \\
\hline & Discount of regular price & 6,307 & $(38.46)$ & Negative \\
\hline & Constant & -147.0 & $(121.5)$ & \\
\hline & Sigma & $46.60^{* * *}$ & * $-9,002$ & \\
\hline & Observations & 105 & & \\
\hline & Uncensored observations & 37 & & \\
\hline & $\operatorname{LR} \chi^{2}(16)$ & 75.61 & 113.84 & \\
\hline & Prob $>\chi^{2}$ & 0.0001 & 0.001 & \\
\hline & Pseudo $R^{2}$ & 0.26 & 0.79 & \\
\hline & Log likelihood & -108.09 & -14.68 & \\
\hline
\end{tabular}

TABLE 2 Percentage of Spending Beyond the Deal Promotion Face Value on Grouper and on the Other Group Sites (\%)

\begin{tabular}{lrr}
\hline Percentage of customers & $(1)$ & $(2)$ \\
\hline $0-10$ & 45,00 & 61,00 \\
$11-25$ & 34,00 & 21,00 \\
$26-50$ & 13,00 & 11,00 \\
$51-75$ & 6,00 & 5,00 \\
Above 75 & 2,00 & 2,00 \\
\hline
\end{tabular}

NOTES Column headings are as follows: (1) Grouper, (2) other deal platforms.

product, the most important is how many among them are first time customers. Hypothesis H1.4. is supported at 5\% significance level. New customer acquisition efficacy is a key driver in group buying promotion evaluation, because if the existing customers come with coupons for the 
TABLE 3 New Customer Acquisition on Grouper and on the Other Group Sites (\%)

\begin{tabular}{lrr}
\hline Percentage of customers & $(1)$ & $(2)$ \\
\hline $0-10$ & 11,50 & 24,00 \\
$11-25$ & 15,50 & 16,00 \\
$26-50$ & 19,00 & 16,00 \\
$51-75$ & 20,00 & 15,00 \\
Above 75 & 34,00 & 29,00 \\
\hline
\end{tabular}

notes Column headings are as follows: (1) Grouper, (2) other deal platforms.

TABLE 4 Promotional Profitability by Featuring Deals on Grouper and Other Deal Sites, Evaluated by Companies (\%)

\begin{tabular}{lrr}
\hline How merchants characterise promotions' profitability? & $(1)$ & $(2)$ \\
\hline We spent significant amount of funds for the promotion & 3,92 & 12,50 \\
We spent small amount of funds for the promotion & 9,80 & 12,50 \\
We broke even & 23,53 & 32,14 \\
We made small profit through the promotion & 48,04 & 37,50 \\
We made substantial profit through the promotion & 14,71 & 5,36 \\
\hline
\end{tabular}

Notes Column headings are as follows: (1) Grouper, (2) other deal platforms.

service or product that anyway would pay full price, then it can produce cannibalization. $34 \%$ of participated companies answered that running group deal promotion on Grouper they offered their services mostly to new customers (over $75 \%$ were new). $88.5 \%$ of the respondents reported that they have over $10 \%$ new customers running promotion on Grouper vs. $76 \%$ running promotions on other group buying sites. Table 3 shows efficacy of the promotion in new customer acquisition on Grouper and on the other group sites.

Profitability of the deals output characteristics is also important factor of the probability that merchant will repeat the daily deal. Hypothesis $\mathrm{H} 1.1$ is supported at $10 \%$ significance level. Grouper promotions were profitable for $62,7 \%$ of the companies vs. 42 , and $9 \%$ of the companies running promotions on other group buying sites. Dholakia (2010) conducted a study of 150 businesses which had used a Groupon group buying deal. He found that the Groupon promotion was profitable for $66 \%$ of the study participants. Table 4 shows how survey participants evaluated promotion's profitability featuring deals on Grouper and other deal sites.

To make customers brought to the company' doors repeated or a reg- 
TABLE 5 Percentage of Repetition Customers Gained by Deal Promotion on Grouper and on the Other Group Sites (\%)

\begin{tabular}{lrr}
\hline Percentage of deal users that became repeat customers & $(1)$ & $(2)$ \\
\hline o & 8 & 21,00 \\
Up to 10 & 32 & 39,00 \\
$10-25$ & 27 & 16,00 \\
$26-50$ & 18 & 10,00 \\
Above 51 & 15 & 14,00 \\
\hline
\end{tabular}

NOtes Column headings are as follows: (1) Grouper, (2) other deal platforms.

ular customer is the most important benefit that companies can gain running group deal promotions. In essence, a price promotion succeeds when it entices new customers to try a particular offering through a compelling offer, and they like it so much that they buy it repeatedly, becoming the firm's relational customers (Dholakia 2006). Hypothesis $\mathrm{H} 1.2$ has ambiguous and statistically not significant impact on merchant's intention to repeat daily deal. $27 \%$ of the participants answered that in case of Grouper promotions they gained 10-25\% repeat customers and $18 \%$ managed to win repeat 26 to $50 \%$ customers. Table 5 shows percentage of repetition customers gained by deal promotion on Grouper and on the other group sites. $60 \%$ of the promotions on Grouper gained over $10 \%$ regular customers and $40 \%$ on the other sites.

Hypothesis $\mathrm{H} 1.5$ has ambiguous and statistically not significant impact on merchants' intention to repeat the daily deal. $64 \%$ of the respondents reported unredeemed coupons to $5 \%$ and the rest or $36 \%$ had unredeemed coupons over $5 \%$ of the purchased coupons. The unredeemed coupons' rate can be considered from 2 aspects. First the unredeemed coupons are direct profit from the promotion because the merchant receives payment for all coupons sold regardless of the redemption. Beside, after the redemption period the unredeemed coupons lose the promotional value but the buyer can use it for products or services for the price paid for the coupon or he can pay the difference in the price (the discounted amount) to get the product/service he firstly bought on a deal. Second, the unredeemed coupons should not be viewed as a profit because the company loses potential new customers that can become repeat customers with lifetime value. The question remains if the merchants feel that the unredemption rate has a positive or negative impact on the promotion.

The correlation of the firm characteristics with merchants' intention to 
repeat the offer to group buying site is positive by category of the companies. $\mathrm{H} 2.2$ is suported at $10 \%$ significance level. Other firms characteristics like number of employees, age, and type of promotion company does are ambiguous and $\mathrm{H} 2.1, \mathrm{H} 2.3$ and $\mathrm{H} 2.4$ do not statistically significant impact the intention on repetition of the daily deal.

Empirically, also, the effect is found to be positive on the coupons sold for the given promotion offered at group buying site, but does not statistically significant impact the intention to repeat the daily deal. As expected, discount on regular price is negatively but not statistically significant impacts the intention for daily deal repetition. $\mathrm{H} 3.1$ and $\mathrm{H} 3.2$ are not supported. This suggests that drivers that will push merchants to repeat the deals offeres are profitability, spending beyond the coupon, new customers brought in the company by the given promotion, and also intention is diverse among different categories of businesses.

\section{Limitations and Future Research}

To enable a correct interpretation of the study's results, it is important to acknowledge its limitations. Like any survey-based study, our results are susceptible to a non-response bias, i.e., the possibility that those who did not respond to our survey were systematically different from those that did participate. Response rate we obtained is $20 \%$. It is as well worth to be mention as limitation that the survey based methodology also means that all performance metrics are assessed based on self-reports provided by business decision makers. Such information is based on subjective assessments of respondents and may be inaccurate in reflecting actual customer behaviours. Nevertheless, since these individuals will make future decisions regarding daily deal promotions, it can be argued that their assessments, even though subjective, are what matters. Finally, we note that $55 \%$ of the companies offered deal on other sites like: Kupinapopust, Kupime, Kolektiva, Sakampopust etc., and we made comparison with all companies.

The findings that restaurants and retailers (store-fronts and offline) are having a more difficult time making daily deals work compared to other industries, can challenge the researchers for future work in this new group buying industry.

\section{Conclusion}

There are some suspicions in the literature regarding sustainability and future of group buying promotion, even though they gained great popu- 
larity. This study addresses the question of sustainability through investigation of merchant's intention to repeat the daily deals offers and gives important knowledge to understand the real potential associated with daily deal promotions to merchants. Even though group buying promotional tool, as every other promotion aims to drive store traffic and increase product demand and brand awareness, small and medium sized businesses in case of deal promotions also seek to generate residual benefits from the deal in the form of opportunities to gain profit, to upsell on regular price, to gain new customers and to keep them as repeat customers. The performance of group buying deals promotions using Grouper internal database and by conducting online survey was investigated. Strong support in the tobit model is given to spending beyond the coupon (h1.3), followed by new customers brought to the business (h1.4) and the profitability of the deals output (h1.1). Repeat customers and non-redemption was found to have ambiguous and statistically not significant impact on merchant's intention to repeat daily deal (h1.2 and h1.5). The correlation of the firm characteristics with merchants' intention to repeat the offer to group buying site is positive and statistically significant by category of the companies (h2.2), while other firms characteristics like number of employees, age, and type of promotion company does are ambiguous and statistically not significant (h2.1, h2.3 and h2.4). Number of sold coupons has positive, but statistically not significant impact on merchant's intention to repeat daily deal (h3.1), while discount on regular price has negative but statistically negative impact $\left(\mathrm{h}_{3.2}\right)$.

The findings of this study suggest that drivers that will push merchants to repeat the deals offers are spending beyond the coupon, new customers brought in the company by the given promotion, profitability, and also intention is diverse among different categories of businesses. The findings can be used by the group deal sites, so that they can advise merchants to make the deal attractive for the customers, so that the deal will reach more sales and on the other hand the merchant will be satisfied from the promotion, in order to become a repeating customer for the deal site. One suggestion is to design the deals in a manner that encourages cross selling. For example, for restaurants it is always better to offer food or package of food that is not including drinks so that the merchant makes a direct profit from the particular deal from the coupon customers. For beauty salons and spas it is better not to bundle many services in one package because this way the target of the potential customers is smaller and the merchant won't be able to do cross selling on other services. When 
it comes to cross selling it is an incentive to offer an extra discount for instance $20 \%$ discount on other services or products that are not included in the coupon in order to achieve cross selling. For example a restaurant promotion for launch package for 2 persons can favour a particular wine company by giving $20 \%$ discount on a bottle of with and the merchant can negotiate better prices with the wine producer for the cross selling promotion.

\section{References}

Anand, K. S., and R. Aron. 2003. 'Group Buying on the Web: A Comparison of Price-Discovery Mechanisms.' Management Science 49 (11): 1546-62.

Bazilian, E. 2011. 'Has the Daily Deals Market Reached Its Breaking Point?' http://www.adweek.com/news/technology/has-daily-deals-market -reached-its-breaking-point-134958

Bilinska-Reformat, K., and B. Reformat. 2011. 'Group Buying as a Source of Competitive Advantage of Polish Small and Medium-Sized Enterprises.' In Proceedings of 19th Annual Conference on Marketing and Business Strategies for Central and Eastern Europe, 3-19. Chicago: DePaul University; Vienna: University of Economics and Business Administration.

Blattberg, R. C., and S. A. Neslin. 199o. Sales Promotion: Concepts, Methods, and Strategies. Englewood Cliffs, NJ: Prentice Hall.

Byers, J. W., M. Mitzenmacher, and G. Zervas. 2012. 'The Group Effect on Yelp Ratings: A Root Cause Analysis.' In Proceedings of the 13 th ACM Conference on Electronic Commerce, 248-65. New York: ACM.

Cao, Z., K. L. Hui, and H. Xu. 2018. 'When Discounts Hurt Sales: The Case of Daily-Deal Markets.' Information Systems Research 29 (3). https://doi.org/10.1287/isre.2017.0772

Cremer, J. 1984. 'On the Economics of Repeat Buying.' RAND Journal of Economics 15 (3): 396-403.

Dholakia, U. M. 2006. 'How Customer Self-Determination Influences Relational Marketing Outcomes: Evidence from Longitudinal Field Studies.' Journal of Marketing Research 43 (1): 109-20.

- 2010. 'How Effective Are Groupon Promotions for Businesses?' Working Paper, Rice University, Houston.

Dong-Hun, L. 2009. 'Consumption Trends for 2009.' SERI Quarterly 2 (1): $100-5$.

Erdogmus, I. E., and M. Cicek, 2011. 'Online Group Buying: What Is There for the Consumers?' Procedia: Social and Behavioral Sciences 24 (15): 308-16.

Geron, T. 2011. 'First Facebook, Now Yelp Scaling Back Daily Deals.' http:// www.forbes.com/sites/tomiogeron/2011/o8/30/first-facebook-now 
-yelp-scaling-back-daily-deals-report

Grandhi, S., G., R. Chugh, and S. Wibowo. 2016. 'An Empirical Study of Customers' Purchase Intentions from Australian Group Buying Sites.' Journal of Internet and e-Business Studies. https://ibimapublishing.com/ articles/JIEBS/2016/732154/732154.pdf

Greene, W. H. 2003. Econometric Analysis. Upper Saddle River, NJ: Prentice Hall.

Greenleaf, E. A. 1995. 'The Impact of Reference Price Effects on the Profitability of Price Promotions.' Marketing Science 14 (1): 82-104.

Gupta, S., R. Weaver, T. Keiningham, and L. Williams. 2012. 'Are Daily Deals Good for Merchants?' Harvard Business School Background Note 513-059, Boston, MA.

Guy, S. 2012. 'Groupon Founders Tally Billions in Paper Losses.' http://www .suntimes.com/business/12998739-420/groupon-founders-tally-billionsin-paper-losses.html

Heussner, Ki M. 2012. 'Closure of CityPockets Provides Window onto Shakeout in Daily Deal Business.' http://gigaom.com/2012/05/10/ closure-of-citypockets-provides-window-onto-shakeout-in-daily-deal -business/

Kamenec, K. 2012. 'Travelzoo Ceo Chris Loughlin, Bases Daily Deal Industry Dynamics.' http://www.dailydealmedia.com/724travelzoo-ceochris-loughlin-bashes-daily-deal-industry-dynamics/.

Kauffman, R. J., and B. Wang. 2001. 'New Buyer's Arrival under Dynamic Pricing Market Microstructure: The Case of Group Buying Discounters on the Internet.' Journal Management INFORM Systems 18 (2): 15788 .

- 2002. 'Bid Together, Buy Together: On The Efficacy Of GroupBuying Business Models In Internet-Based Selling.' Paper presented at the 5th Annual University of Minnesota Electronic Commerce Conference, 27-28 March, Minneapolis, MN.

Kotecha, A. A., J. Leibowitz, and I. MacKenzie. 2008. 'How Retailers Can Make the Best of a Slowdown.' McKinsey Quarterly no. 4: 104-7.

Kotler, P., and G. Armstrong. 2009. Principles of Marketing. Upper Saddle River, NJ: Prentice Hall.

Li, S. 2012. 'Groupon Faces Growing Doubts about Its Credibility and Viability.' http://articles.latimes.com/2012/apr/o6/business/la-fi-groupongrowing-pains-20120407

Mazen, A. 2012. 'Groupon's Biggest Obstacle Is Merchant Retention.' http:// seekingalpha.com/article/317246-groupon-s-biggest-obstacle-is -merchant-retention

Narasimhan, C. 1984. 'A Price Discrimination Theory of Coupons'. Marketing Science 3 (2): 128-47. 
Nelson, P. 1970. 'Information and Consumer Behavior.' Journal of Political Economy 78 (2): 311-29.

- 1974. 'Advertising as Information.' Journal of Political Economy 82 (4): 729-54.

Reisinger, D. 2011. 'Struggling BuyWithMe May Live on as Unit of Gilt, Report Says.' http://news.cnet.com/8301-13506_3-20127170-17/strugglingbuywithme-may-live-on-as-unit-of-gilt-report-says/

Sherr, I. 2010. 'Online Coupons Get Smarter - Groupon, Rivals Add Personalized Bargain Staff as Some Merchants Gripe.' Wall Street Journal, 25 August.

Stulec, I. and K. Petljak. 2010. 'Moc grupne kupovine'. Suvremena trgovina 35 (6): 22-5.

Stulec, I., K. Petljak, and R. Vouk. 2011. 'The Role of Internet in Empowering Consumers: The Case of Group Buying.' In Proceedings of MSKE 2011: Managing Services in the Knowledge Economy, 730-41. Largo Tinoco de Sousa: Universida de Lusíada de Villa Nova de Famalicão.

Subramanian, U., and R. C. Rao. 2016. 'Leveraging Experienced Consumers to Attract New Consumers: An Equilibrium Analysis of Displaying Deal Sales by Daily Deal Websites.' Management Science 62 (12): $3555-75$.

Taulli, T. 2012. 798 'Daily-Deal Sites Die - in 6 Months.' http://www .investorplace.com/ipo-playbook/798-daily-deal-sites-die-in-6 -months/

TechCircle. 2013. 'Lack of Merchant Focus Tripped up Indian Group Buying Sites: Groupon India CEO AnkurWarikoo.' http://techcircle .vccircle.com/2013/o3/26/lack-of-merchant-focus-tripped-up-indiangroup-buying-sites-groupon-india-ceo-ankur-warikoo/

Vacanti, V. 2011. 'Is Groupon Bad for Small Businesses?' http://techcrunch .com/2011/o7/o2/groupon-small-businesses/

Varian, H. R. 1980. 'A Model of Sales.' American Economic Review 70 (4): 651-9.

Walters, R. G., and S. B. MacKenzie. 1988. 'A Structural Equations Analysis of the Impact of Price Promotions on Store Performance.' Journal of Marketing Research 25(1): 51-63. 


\title{
Vision of Personal Future as a Tool
}

\section{for Supporting Adolescents' Transition to Adulthood}

\author{
Nada Polovina \\ Institute for Educational Research, Serbia \\ npolovina@ipi.ac.rs \\ Smiljana Jošić \\ Institute for Educational Research, Serbia \\ smiljana.josic@gmail.com
}

This article reports on the Vision of personal future scale (VPF), an instrument aimed to assess cognitive clearness, conviction in realization, and the self-directedness of adolescents' envisioning of their personal future. The 13-item scale was applied on 1,969 Serbian adolescents with the aim of exploring general aspects of their anticipations of their personal future. Results show that adolescents highlight the motivational and guiding potential of their own vision of the future. Two factor structures were extracted (named motivational optimistic and cognitive fearful), but each factor was emphasized differently by adolescents. The usefulness of the scale was discussed in the context of youth work and the creation of specific programs aimed to support youth development.

Key Words: future thinking, vision of personal future scale, adolescents, positive youth development

JEL Classification: I20, 015

https://doi.org/10.26493/1854-6935.17.239-258

\section{Introduction}

Adolescence is considered to be a core period of life for the construction of a meaningful comprehensive picture of one's own future, thus outlining an important motivational framework and trajectory of the desired and/or expected development toward adulthood (Arnet 2000; Lloyd 2005). Researchers and practitioners addressing the issue of transition to adulthood have recognized the vital importance of providing effective support services that will support adolescents to prepare for emerging transition via envisioning and designing their lives toward positive futures (Guichard 2005; Lerner et al. 2005; Schmid, Phelps, and Lerner 2011). The benefits of such preparation are particularly apparent 
for current generations of young people, whose transition to adulthood is marked with challenges greater than ever before (Crocetti et al. 2012). Induced by the transforming impacts of globalisation on all spheres of public and private life, new ways of coming of age (Arnett 2002) are characterized with abundant developmental tasks, to be performed in the context of the uncertainties of constantly changing living in 'liquid modernity' (Bauman 2006). Such a context is marked with lack of a demographic normative (different lifestyle options encompassing time/choice of: finishing education, autonomous living, job/career type, romantic/marital arrangement, becoming a parent) that challenges previous patterns of being and becoming and opens up the important issue of 'navigating' one's own development (Sica et al. 2016).

In order to establish a certain level of certitude and predictability and to maximize the personal benefits of development through this life stage (from 18 to 29 years), a young person needs to have a new approach and new tools. One such tool is related to the management of one's own development in terms of mastery and control over performance of ageappropriate developmental tasks and achieving a state of general well being. One of the first steps in the navigation of own development is the creation of a vision of one's personal future i.e. a cognitive framework that sets up important goals and anticipates and motivates necessary action. Stressing the importance of a self-management approach to one's individual life course and proposing the construct 'vision of personal future,' we seek to extend our understanding of young people's future-oriented phenomena in the context of building their strengths and thriving to fulfil their goals.

Similar to some other post-socialist societies, Serbia does not offer sufficient support for the positive development of new generations of young people (aged 16-29) which account for $18.35 \%$ of the total population (Statistical Yearbook of the Republic of Serbia 2017). The majority of them $(83.5 \%)$ attend/participate in secondary education and near half $(46 \%)$ is enrolled in tertiary education (Statistical Yearbook of the Republic of Serbia 2014). In that regard, the domain of education should be suitable for developing youth support programs, although educational institutions have not recognized the issue of thinking about the future and shaping future goals as important research and practice-oriented themes. Recent sociological studies provide insight into elements of the disadvantages of social position and the role of youth in Serbian society. The results of these studies indicate that transition to adulthood for current genera- 
tions of youth in Serbia takes places in the context of a substandard and unstable economy (around 50\% of youth is unemployed, Mojić 2014), a blurred value framework (declining traditional and authoritative values; liberal values still not accepted, Mojić 2014) and contradictions in the social articulation of life that derive from value normative dissonance (the difference between value systems and norms and how things function in reality, Mrđa 2011). In that regard, declarative rhetoric in public discourse about the key role of young people in the development of society is in contradiction with the lack of efforts by power holders to establish realistic foundations and mechanisms for young people to truly become agents in decision-making society-development processes. Moreover, besides the fact that for youth all choices are seriously brought into question by the real social situation and social circumstances in which they live, young people are also exposed to stereotypes and misunderstandings about their role and what's expected of them (Mrđa 2011, 120). In addition, they are also immersed in living contexts characterized by a low quality of sociocultural capital (quasi-institutional changes; poor level of collective benefits that derive from cooperation between individuals and groups) which undermine the development of trust and reciprocity between groups and individuals. Having all this in mind, it is not surprising that the terms used to describe young generations in the last ten years are most often: apathy, un-initiative, and inertia (Cvejić 2006; Mrđa 2011). In addition, emigration aspirations are widespread - near half of the youth population wants to emigrate, although a smaller proportion actually does so (Tomanović and Stanojević 2015). Such a situation accentuates the importance of youth programs that aim to strengthen young people's efforts to find the best possible way to manage their own development toward positive and life satisfying outcomes.

\section{Conceptual Framework}

This study follows a Positive Youth Development (PYD) paradigm created at the end of the old and the beginning of the new millennium as a new approach to the study, developmental support, and enhancement of young people's potentials, as well as a new approach to looking at what is normative for adolescents' development (Benson 2003; Bowers et al. 2010; Catalano et al. 2004; Larson 2000; Li, Lerner, and Lerner 2010; Youngblade et al. 2007). In that regard, the term PYD refers to a number of interrelated fields of considerations: theoretical considerations about processes of development and growth of young people; philosophy of ap- 
proach to youth programming; program/organization-based practices of fostering the positive development of youth; and the design of public policies relating to youth development (Hamilton, Hamilton, and Pittman 2004). Thus PYD is characterized by a number of constructs and a comprehensive, widely-inclusive approach regarding the creation of positive youth development programs as well as different instruments created to examine many different youth development constructs (Catelano, Gavin, and Markham 2010).

The PYD paradigm advocates new approaches to development based on values and principals considered to be important for living in the 21st century. The domain of education is seen the first and most important area for the affirmation of new values and norms. In the PYD theoretical framework, equal significance is attached to the strength of the individual and the supportive conditions of the environments in which the development takes place. The central point of the approach is the emphasis on young people's strengths and on promoting the development of functionally valuable behaviours, elaborated as the development of key cognitive, emotional, behavioural, and social competencies, as well as the fostering of young people's self-determination and belief in the future.

It is important to emphasize that in the PYD approach defining the constructs also means defining objectives of the approach, as well as generating criteria for program outcomes. In accordance with the topic of our paper, we briefly present only two Py constructs: 'beliefs in the future' and 'self-regulation.' The term 'beliefs in the future' refers to 'an internalisation of hope and optimism about future outcomes' (Sun and Shek 2012, 1), but also includes goal-directed thought (long-range goal setting related to valued and attainable goals) and orientation towards goal-directed activities (Catalano et al. 1998). Positive future expectations are regarded as important personal strengths of individuals, a sort of tool that can provide an individual with better outcomes in dealing with major developmental issues (Stoddard and Pierce 2015). Within PYD paradigm, beliefs (i.e. hopeful expectations for the future) are considered to be theoretically related to the 'self-regulation' construct (Schmidt, Phelps, and Lerner 2011). Developing 'belief in the future' implies envisioning future goals and events, thus creating the ground for regulation of personal behaviour and emotions in order to bring about the imagined future (Taylor 2011).

Integrating the stances of different authors on self-determination, Catalano et al. (1998) defined self-determination as the ability to think 
for oneself, to take action consistent with that thought, and to chart one's own course. This construct elucidates the process through which the strengths of youth (intentional self-regulating skills; developing ability to live and grow by self-determined internal standards and values) could be developed through youth development programs (Catalano et al. 1998; Mueller et al. 2011). Schmid, Phelps and Lerner (2011, 1127) explored relations among adolescents' hopeful future expectations and intentional self-regulation over time and found that earlier hopeful expectations for the future may be influential for later intentional self-regulation abilities, and that both constructs were strong predictors of PYD in middle adolescence. Mueller et al. (2011) examined the relationship between adolescents' self-regulation skills (selection, optimization, and compensation) and the adolescents' participation in youth development (YD) programs through Grades 8 and 9 in predicting Grade 10 PYD contribution. Results indicated that while self-regulation skills alone predicted PYD, selfregulation and YD program participation both predicted contribution to PYD. Taylor (2011) reports on a program of research on mental simulation as a potentially valuable tool for exercising anticipation of the future and managing the reaching of future goals and events.

One of the starting points for developing self-regulating skills in the service of positive development is the creation of a cognitive framework to articulate an individual's important goals, expected to be realized in the future.

\section{Vision of Personal Future}

Although the issue of ways in which young people think about and prepare for their desired and expected future has been analyzed using several conceptual frameworks by various authors (Johnson, Blum, and Cheng 2014; Lens et al. 2012; Markus and Nurius 1986; Nuttin and Lens 2014; Seginer 2009), this study refers to young people's future orientation by drawing upon the PYD framework and introducing the psychological construct 'vision of personal future' as a one that in specific form integrates aspects of 'beliefs in the future' and 'self-regulation.' The construct originates from the field of leadership and organization development (Strange and Mumford 2002; Mhatre and Riggio 2014) but recently appeared as relevant for understanding the processes of individual development, as well (Scott, Lonergan, and Munford 2005; Blue-Banning, Turnbull, and Pereira 2002; Polovina, Ćirović, and Jošić 2013).

Analyzing different definitions of the term 'vision', Strange and Mum- 
ford $(2002,344)$ stressed that all definitions imply that vision may be conceived of a set of beliefs about how people should act, and interact, to attain some idealized future state. According to them vision of the future is a distinct image of an individual (or organizational) future, a framework involving a set of idealized future goals as well as directions for and coordination of activities relevant to future goal attainment (Strange and Mumford 2005, 122). Vision of the future implies the involvement of a cognitive aspect (consciously represented and self-reported images regarding the future, judgment of internal versus external causality) and motivational-affective aspect (goals that are of emotional importance to the person, beliefs about realization of vision). This is in line with Strange and Mumford's stance (2002, 344-5) that vision does not, by itself, ensure desirable outcomes, but that articulation of a vision (vision contents/goals) directs and motivates behaviour (specifies direction and purpose), while the common framework enables organization of action around future goals. The features offered by Strange and Mumford provide the basis for making a distinction between a common framework of vision (general beliefs related to future and future actions) and vision contents (goals in different life domains).

Partly similar to well-established psychological constructs (detailed in Gril et al. 2018) relating to issue of images that adolescents develop about the future, future time perspective, (Nuttin and Lens 2014), future orientation (Seginer 2009), possible self (Marcus and Nurius 1986), the construct 'vision of personal future', in our view, has some specific features that are relevant for our approach to the issue under consideration. In that regard, we define 'vision of personal future' as a self-relevant cognitive framework related to imagined/anticipated future goals and their attainment. Envisioning the personal future implies potential behavioural control and self-direction of individual development. Such a cognitive representation of the future may be more or less cognitively clear and more or less stable, as well as being pervaded with a sense of certainty or uncertainty regarding its fulfilment. We argue for the separation of general aspects of such a self-relevant framework and the domain-specific thematic aspects of the visions of personal future.

\section{Measuring Adolescents' Subjective Images of Future}

For more than last 50 years, as pointed out by Seginer (2003, 4), the majority of future-oriented research has focused on thematic (content) aspects of subjective images of personal future, based on data collected 
by means of qualitative i.e. open-ended methods (Nurmi, Poole, and Kalakoski 1994; Nurmi, Poole, and Seginer 1995; Unemori, Omoregie, and Markus 2004; Türken et al. 2016; Heggli, Haukanes, and Tjomsland 2013). However, with the proliferation of the PYD approach, numerous quantitative self-report based instruments entered the field, indicating its usefulness for supporting the development of functionally-valuable youth behaviours. A comprehensive review of these instruments (including overlaps but also nuances of conceptual differences) goes beyond the scope of this paper. With regard to the topic and goal of our work, we will outline three scales (their format and conceptual background) that, on different grounds, have points of contact with our Vision of Personal Future Scale (VPF). This are: Personal Growth Initiative Scale (P G I, Robitschek 1998; Robitschek, Ashton, and Spering 2012), Time Perspective Inventory (ZTPI, Zimbardo and Boyd 1999) and Visions About Future Scale (va F, Ginevra et al. 2017).

Personal Growth Initiative Scale. (P GIS) was initially developed in the context of a wilderness program for people who were in life transition and it addressed specific objectives: personal growth related to life goals, purpose and balance (Robitschek 1998). The initial pool of items was developed by brainstorming and included clarifying understanding of the issue of the developmental stage and transition i.e. process of change, vision of the future, and setting of goals. The process of validation of an initially 9item Likert-type scale indicated that the scale was particularly relevant for exploring undergraduates and college students' engagement in processes of growth across several potential personal growth domains (Robitschek 1999; Robitschek and Cook 1999). Ten years later, the scale was redesigned (PGI-II, Robitschek et al., 2012) in terms of its content (derived from theory, addressing only the issue of intentional personal growth) and number (16-item Likert-type scale). The PGI-II scale is in use as a multidimensional instrument that captures 4 subscales (Readiness for Change, Planfulness, Using Resources, and Intentional Behaviour). It is indicated that the scale has the potential to cultivate active, intentional engagement in the process of personal growth through support based programs, such as those related to the exploration of issues of career, vocational identity, and coping styles (Robitschek and Cook 1999). Comparing the items of PGI and PGI-II scales and items of our VPF scale, we found no similarities.

Zimbardo Time perspective Inventory is a theoretically-based instrument focused on fundamental dimension in the perception of time, im- 
plying cognitive processes parcelling out human experience into past, present, and future temporal frames (Zimbardo and Boyd 1999, 1271). Achieving a balanced time perspective is considered to be one key to learning how to live a fulfilling life (Boniwell and Zimbardo 2004, 165) confirmed results of different studies. The inventory is offered both in extensive (56 items including 5 dimensions related to Future, Present and Past time perspective) and short forms (13 items relating to Future time; 9 items related to Present time). Here we highlight the shorter Future time perspective scale, a zone in which our plans, commitments, and anticipated experiences are situated, as well as our expectations for personal well being. This is particularly important when young people are the focus of consideration (Zimbardo and Boyd 1999). Comparing the items of Future time perspective and items of our VPF scale we found that only one item is similarly worded and with similar meaning (ZFTP - 'Thinking about the future is pleasant to me'; VPF 'I enjoy thinking about the future').

Visions About Future Scale (Sgaramella et al. 2017) is a recently-constructed scale, aimed to inclusively assess optimism, pessimism, and hope in adolescents. The three constructs are positioned as potentially important components of positive views about the future, particularly relating to adolescents' involvement in career planning. Items were developed from relevant theoretical conceptualisations and research. Psychometric evaluation crystallized 19 items with a five-point scale response format. Comparing the items of VBS and items of our VPF scale we found that only two items are similarly worded and with similar meaning (v в s 'Even if I encounter difficulties in the future I will continue being optimist,' 'It is useless to hope for the future: I will not be able to do what I have in mind'; VPF 'I am determined to realize my ideas about the future despite the obstacles I might encounter'; 'Probably my ideas about the future will not come true').

\section{Overview of the Study}

In this paper, we present part of data collected in a broader survey designed to contribute to better understanding of challenges young people face in their transition to adulthood and to instigate the design of positive youth development programs for supporting positive transition. The survey was inspired by insights gained in preliminary qualitative research (Polovina, Ćirović, and Jošić 2013) but based on a quantitative methodology. The central part of the survey comprised a comprehensive question- 
naire containing five sections : general aspects relating to adolescents' envisioning of their personal future, and four domain-specific aspects (education and career; finance and housing; romantic relations/marriage and parenthood; and place of residence).

The present study addressed general aspects of adolescents' envisioning of their personal future. Our research question relates to the development and evaluation of some psychometric properties of Vision of Personal Future Scale (VPF): a self-report instrument developed to access characteristics of adolescents' general cognitive representation of envisioned future. The purpose of the evaluation was to shed light on the general characteristics of youth vision for their personal future and to consider the usefulness of this instrument in the field of youth work. Two steps in the development of the scale are presented: a pilot study and the main study, conducted on a representative sample of adolescents in Serbia.

\section{Method}

SCALE DEVELOPMENT

The Vision of Personal Future (further on VPF) was initially developed to assess the characteristics of young Serbs' developmental strivings and opportunities in their future life. Items for the scale originated from analysis of a previous qualitative study and pilot study. These studies revealed the same specific components in cognitive and motivational segments of young people's vision of their personal future. Both studies helped researchers to construct items for the final version of the VPF scale

Based on analysis of qualitative materials (a short essay form of vision of personal future, see. Polovina, Ćirović, and Jošić 2013) we realized that adolescents differ in terms of articulation of their visions of personal future and in their determination to accomplish them, but also regarding the topics to which they are focused. Those findings led us to construct a 5 -item Likert-type scale. Reliability analyses of this scale, measured by Cronbah alpha coefficient, was $\alpha=0.71$. The principal component analyses extracted one factor out of these items. This one factor explains the total of $46 \%$ of variance.

Further work on the VPF scale led us to construct a 13-item Likert-type scale which was developed to assess a time-limited general framework concerning the future. Following Strange and Mumford's (2002) abovementioned stance relating to a distinction between a common/general 
frame of vision, and vision contents, we created VPF as a basic common frame screening tool which could be upgraded (more about the upgraded version in Gril et al. 2018) in order to address different contents, e.g. contents relating to different aspects of the educational, career and workrelated interests and aspirations of young people. This two-step (general framework, concrete themes) approach offers different possibilities to professionals, since it is constructed to be used by them in the context of creating youth development programs.

In line with previous academic considerations (Nuttin and Lens 2014; Seginer 2009; Transdorf 1983) the scale was created to focus on the two important general components of future-oriented thinking: cognitive aspect (includes 6 items relating to clarity of vision; stability of vision; judgment of internal versus external causality) and the motivationalaffective aspect (includes 7 items related to decisiveness in fulfilling a vision; hopes/optimism and fears about fulfilling the vision). The Cronbach alpha reliability coefficient of the scale was $\alpha=0.78$. The items are presented in table 1.

\section{PARTICIPANTS}

In the pilot study, during the scale development, the sample consisted of 245 students from 5 high schools from different parts of Serbia (64\% girls and $36 \%$ boys, mean age 18 ).

The main study was conducted at the beginning of the 2015/2016 school year and included stratified random samples of Serbian high school students studying in the last grade of three types of educational institutions: gymnasiums, professional, and vocational schools. The sample consisted of 1,969 participants from 94 schools. Serbia was divided into three geographical regions. Schools were drawn from each region from urban and rural areas by a stratified, random procedure. The sample consisted of $52 \%$ girls and $48 \%$ boys, with the mean age of 17.84 years. Out of the total number of adolescents, $21 \%$ were enrolled in gymnasiums, $68 \%$ were studying in professional schools, and $11 \%$ were students in vocational schools.

\section{PROCEDURE}

The pilot study was conducted in April 2015 and the main study in November 2015. All students were instructed to thing about their own life in the next 10-15 years and to imagine themselves as $27-32$ years old person. The adolescents answered the questionnaire on visions of the future collectively in one school class. Adolescents were asked how much 
they agree with the statement they read with the help of a five degree scale where 1 means 'do not agree at all' and 5 means 'totally agree.'

\section{Results}

\section{DESCRIPTIVE STATISTIC}

In table 1, we show descriptive data of the items in order to present the adolescents' answers. We have summarized data on the scale and shown polarized answers both with the data on average scores and standard deviations. From that table, we can see that adolescents highly agreed with items that emphasize the three aspects of vision of personal future - motivation, persistence, and guidance (items 3 , 7, and 9). On the other hand, our participants disagreed with the items related to instability, fearfulness, and avoidance concerning the vision of personal future (items 4, 11, and 13).

\section{FACTOR ANALYSIS}

The analysis of the main components with Promax rotation with Kaiser normalization confirmed that 13 items could be grouped into 2 factors which explains the total of $38 \%$ of variance (see table 2). From table 3 , which shows the saturation factors, we can see that the first factor (named motivational-optimistic) groups items related to motivation and positive feelings, and expectations (clarity of vision, acting in accordance with the vision, decisiveness and persistence in fulfilling the vision, positive feelings and optimism). The second factor (named cognitive fearful) groups items related to cognitive processes and unpleasant emotions (fearful uncertainty, instability, focus on external causality, recognition of guiding aspect of the vision). The obtained factors were named on the base of items content and in line with previous academic considerations (especially Nuttin and Lens 2014; Seginer 2009; Transdorf 1983) that pointed out the cognitive and motivational-affective components of future thinking. This view is corroborated with comprehensive analysis of Andre et al. $(2018,6)$ regarding a different future time construct' structure that 'may include: (a) cognition, (b) the combination of cognition and behavioural intention, (c) the combination of cognition and affect, and (d) a mixture of cognition, behavioural intention, and affect.'

\section{RELATIONS WITH SCHOOL TYPE AND GENDER}

We calculated mean scores for two factors of VPF scale on the basis of the extracted factors. On those two factors we checked their relations to gender and school type. Adolescents showed significant gender differences in 
TABLE 1 The Percentage of Answers on the Items in Relation to the Future and Descriptive Parameters Mean and Standard Deviation

\begin{tabular}{llrrrrrrr}
\hline Items & $(1)$ & $(2)$ & $(3)$ & $(4)$ & $(5)$ & M & SD \\
\hline 1 & I have a clear picture about my future & 4.0 & 4.7 & 18.5 & 41.5 & 31.2 & 3.91 & 1.02 \\
\hline 2 & $\begin{array}{l}\text { Thinking about how my life will look in } \\
\text { the future will fill me with anxiety and } \\
\text { uncertainty }\end{array}$ & 8.5 & 11.8 & 26.4 & 30.9 & 22.5 & 3.47 & 1.21 \\
\hline 3 & $\begin{array}{l}\text { Decisions I make today are influenced } \\
\text { by my wishes and intentions concerning } \\
\text { my future }\end{array}$ & 3.2 & 4.7 & 17.3 & 35.6 & 39.2 & 4.03 & 1.02 \\
\hline 4 & & & & & & & & \\
\hline
\end{tabular}

Notes Column headings are as follows: (1) do not agree at all, (2) disagree, (3) neither agree nor disagree, (4) agree, (5) totally agree.

terms of their agreement with the motivational optimistic $\left(F_{1,1965}=5.602\right.$, $p=0.018)$ and cognitive fearful factor $\left(F_{1,1965}=15.941, p=0.000\right)$. Our data indicated that, concerning both factors, girls on average expressed cognitive and motivational-affective aspects on VPF scale more strongly. This implies that envisioning the future is a concept closer to girls who show- 
TABLE 2 Initial Eigenvalues and Percentages of Explained Variance in the Factor Analysis of the VPF Scale

\begin{tabular}{lrrr}
\hline Factor & Eigenvalues & Percentage of variance & Cumulative percentage \\
\hline 1 & 3.32 & 25.5 & 25.5 \\
2 & 1.66 & 12.8 & 38.4 \\
\hline
\end{tabular}

TABLE 3 Pattern Matrix of Factors v pF Scale after Promax Rotation

\begin{tabular}{|c|c|c|c|}
\hline & $\mathrm{ms}$ & (1) & (2) \\
\hline 1 & I have a clear picture about my future. & 0.682 & \\
\hline 2 & $\begin{array}{l}\text { Thinking about how my life will look in the future will fill me with } \\
\text { anxiety and uncertainty. }\end{array}$ & & 0.603 \\
\hline 3 & $\begin{array}{l}\text { Decisions I make today are influenced by my wishes and inten- } \\
\text { tions concerning my future. }\end{array}$ & 0.567 & \\
\hline 4 & I often change my ideas about the future & -0.348 & 0.488 \\
\hline 5 & I am convinced that I will realize my ideas about the future. & 0.664 & \\
\hline & $\begin{array}{l}\text { In spite of my wishes and dreams, fulfilment of my ideas about the } \\
\text { future will mostly depend on external circumstances and luck. }\end{array}$ & & 0.622 \\
\hline 7 & $\begin{array}{l}\text { I am determined to realize my ideas about the future despite the } \\
\text { obstacles I might encounter }\end{array}$ & 0.682 & \\
\hline 8 & I enjoy thinking about the future. & 0.564 & \\
\hline & $\begin{array}{l}\text { It is important to have an idea of the future, in spite of the fact that } \\
\text { it may not be realized. }\end{array}$ & 0.401 & 0.544 \\
\hline & I think that I have bright future. & 0.658 & \\
\hline & Probably my ideas about the future will not come true. & -0.551 & 0.376 \\
\hline & $\begin{array}{l}\text { The one who doesn't have a clear picture about the future neither } \\
\text { has a guiding idea. }\end{array}$ & 0.358 & 0.409 \\
\hline & I rarely think about how my life will look like. & -0.377 & \\
\hline
\end{tabular}

Notes Column headings are as follows: (1) factor 1: motivational/optimistic, (2) factor 2 - cognitive fearful. Saturations lower than 0.3 were omitted from the table.

cased a clear attitude as opposed to boys who gravitated toward more neutral answers. This is in line with already existing findings (Greene and DeBacker 2004; Seginer and Mahajna 2004).

Regarding the relation between school type and extracted factors, adolescents differ in cognitive fearful factor $\left(F_{1,1965}=4.883, p=0.027\right)$ but not in the motivational optimistic factor $\left(F_{1,1965}=0.102, p=0.749\right)$. Specifically, this means that adolescents from all types of schools (gymnasium and professional and vocational school) agreed less with the cognitive 
fearful aspect of their future, although adolescents from professional and vocational schools had higher scores for this factor. Students from these schools are more concerned about the future and are more anxious about the realization of their future, which is to be expected if we take into account the short time distance to possible employment and taking up the role of an adult in other domains of life.

\section{Final Discussion}

This contribution was designed to shed new light on young people's future-oriented thinking by introducing the construct 'vision of personal future' and stressing its developmental relevance in the process of transition to adulthood. By using the construct 'visions of the future' and creation of the VPF scale we wanted to emphasize the importance of envisioning the future in a cognitive form that include the construction of a general personal framework (basic direction and 'tone' of development), implying the need for self-managing ones own life-course and openness for further thematic elaborations regarding future goals in different life domains. Besides its conceptual and methodological contribution (construct vision of personal future and VPF scale development), our paper provide empirically based grounds for the creation of programs for supporting and empowering young people in the challenging time for transition to adulthood.

As we can see from the presented data (table 1), a high percentage of affirmative answers was obtained on the item relating to importance, emotional significance and motivational potentials of vision of personal future. In that regard, participants in our research confirmed that envisioning one's own future in a way that affirms motivation, persistence and guidance can be a useful 'tool' for a young person's development, but not in a way that is shadowed by instability, fearfulness and avoidance. This finding is in line with Positive youth development conceptualisations and suggested practices of supporting optimization of adolescents' development grounded on enhancing their strengths (Lens et al. 2012; Linley and Joseph 2004). Similar to already existing conceptualisations and research findings (Nuttin and Lens 2014; Transdorf 1983), the results of our study pointed out that adolescents' visions of personal future contained different and somewhat opposing aspects (represented in extracted factors labelled motivational-optimistic and cognitive fearful). When we think about these opposing aspects on the group level, our data indicates that envisioning the future is a concept closer to girls than 
to boys. Namely, girls expressed cognitive and motivational-affective aspects more strongly on the VPF scale, i.e. envisioning the future is a concept closer to girls, who showcased a clear attitude as opposed to boys who gravitated towards more neutral answers. The findings are consistent with the results of previous studies showing that girls thought more about the future than boys (Gjesme 1979), and that female students had fewer negative thoughts about the future than male students (Mello and Worrell 2006). Also, we found opposing aspects of adolescents' visions of personal future relating to the type of school adolescents attend. Expectedly, students from professional and vocational schools are more concerned about the future and are more anxious about the realization of their future (they had higher scores regarding the cognitive fearful aspect of their future) which can be related to the proximity of possible employment and taking up the role of an adult in other domains of life. Both types of difference (gender, school type) call for specific approaches and programs within youth work. On the other hand, considering the issue of opposing aspects of vision of personal future on individual level of functioning (present in general or in relation to some domain-specific goals), the need for youth work and support to their developmental dilemmas have become more obvious.

Given the challenging social and economic contexts in Serbia, reflected in findings of sociological studies pointing to youth social apathy (loss of thrust and reciprocity) and widespread emigration aspirations (Cvejić 2006; Tomanović and Stojanović 2015), our findings based on psychodevelopmental approach indicated that participants in our research have the potential to develop positive and personally motivating perspectives of the future. It is this discrepancy that additionally emphasizes importance of creating youth policy which would give greater impetus to youth work within the educational system, which brings together the largest number of young people. The young are ready for it. The question is, whether society is ready for such an endeavour?

The programs that facilitate preparation of adolescents for optimal 'capitalization' of their potentials and strengths during their transition to adulthood present a challenging task. As already indicated, support programs have to consider different ways of thinking about the future for young males and females, especially those finishing gymnasium, professional, or vocational schools. Furthermore, we want to stress the potential usefulness of our scale and approach for the creation of thematically complementary but different programs for supporting young people in their 
articulation and elaboration of domain-specific goals, plans, and direction of future actions.

\section{Acknowledgments}

This work was supported by the Ministry of Education, Science and Technological Development of Republic of Serbia grant [No. 47008 and 179034; 2011-2019]. Part of the research was presented at the EMAN 2019 Conference.

\section{References}

Andre, L., A. E. van Vianen, T. T. Peetsma, and F. J. Oort, F. J. 2018. 'Motivational Power of Future Time Perspective: Meta-Analyses in Education, Work, and Health.' PLOS One 13 (1): eo190492.

Arnett, J. 2002. 'The Psychology of Globalization.' American Psychologist 57 (10): 774-83.

Bauman, Z. 2006. Liquid Modernity. Malden, MD: Polity Press.

Benson, P. L. 2003. 'Developmental Assets and Asset Building Communities: Conceptual and Empirical Foundations.' In Developmental Assets and Asset-Building Communities: Implications for Research, Policy, and Practice, edited by R. M. Lerner and P. L. Benson, 19-43. Norwell, MA: Kluwer Academic Publishers.

Blue-Banning, M., P. Turnbull, and L. Pereira. 2002. 'Hispanic Youth/Young Adults with Disabilities: Parents' Visions for the Future.' JASH 27 (3): 204-19.

Boniwell, I., and P. G. Zimbardo. 2004. 'Balancing Time Perspective in Pursuit of Optimal Functioning.' In Positive Psychology in Practice, edited by P. A. Linley and S. Joseph, 165-78. Hoboken, No: Wiley.

Bowers, E. P., Y. Li, M. K. Kiely, A. Brittian, J. V. Lerner, and R. M. Lerner. 2010. 'The Five Cs Model of Positive Youth Development: A Longitudinal Analysis of Confirmatory Factor Structure and Measurement Invariance.' Journal of Youth and Adolescence 39 (7): 720-35.

Catalano, R. F., M. L. Berglund, J. A. M. Ryan, H. S. Lonczak, and J. D. Hawkins. 1998. 'Positive Youth Development in the United States: Research Findings on Evaluations of Positive Youth Development Programs.' http://www.aspe.hhs.gov/hsp/PositiveYouthDev99

- 2004. 'Positive Youth Development in the United States: Research Findings on Evaluations of Positive Youth Development Programs.' Annals of the American Academy of Political and Social Science 591 (1): 98-124.

Crocetti, E., M. Scrignaro, L. S. Sica, and E. Magrin. 2012. 'Correlates of Identity Configurations: Three Studies with Adolescent and Emerging Adult Cohorts.' Journal of Youth and Adolescence 41 (6): 732-48. 
Cvejić, S. 2006. Korak u mestu: Društvena pokretliivost u Srbiji u procesu post-socijalističke transformacije. Belgrade: Is IF F.

Ginevra, M. C., T. M. Sgaramella, L. Ferrari, L. Nota, S. Santilli, and S. Soresi. 2017. 'Visions about Future.' International Journal for Educational and Vocational Guidance 17 (2): 187-210.

Gjesme, T. 1979. 'Future Time Orientation as a Function of Achievement Motives, Ability, Delay of Gratification, and Sex.' The Journal of Psychology 101 (2): 173-88.

Greene, B., and T. K. DeBacker. 2004. 'Gender and Orientations Toward the Future: Links to Motivation.' Educational Psychology Review 16 (2): 91-120.

Gril, A., N. Polovina, I. Ćirović, S. Autor, and M. Radulović, M. 2018. 'The Reflections of Value Changes in Adolescents' Anticipation of Possible Career Selves in Slovenia and Serbia.' In Changing Values and Identities in Post-Communist World, edited by N. Lebedeva, 383-403. Cham: Springer.

Guichard, J. 2005. 'Life-Long Self-Construction.' International Journal for Educational and Vocational Guidance 5:111-24.

Hamilton, F., M. Hamilton, and K. Pittman. 2004. 'Principles for Youth Development.' In The Youth Development Handbook: Coming of Age in American Communities, edited by S. Hamilton and M. A. Hamilton, 3-20. Thousand Oaks, m A: Sage.

Heggli, G., H. Haukanes, and M. Tjomsland. 2013. 'Fearing the Future? Young People Envisioning Their Working Lives in the Czech Republic, Norway and Tunisia.' Journal of Youth Studies 16 (7): 916-31.

Johnson, S. R. L., R. W. Blum, and T. L. Cheng. 2014. 'Future Orientation: A Construct with Implications for Adolescent Health and Wellbeing.' International Journal of Adolescent Medicine and Health 26 (4): 459-68.

Larson, R. W. 2000. 'Toward a Psychology of Positive Youth Development.' American Psychologist 55 (1): 170-83.

Lens, W., M. P. Paixao, D. Herrera, and A. Grobler. 2012. 'Future Time Perspective as a Motivational Variable: Content and Extension of Future Goals Affect the Quantity and Quality Of Motivation.' Japanese Psychological Research 54 (3): 321-33.

Lerner, R. M, J. V. Lerner, J. Almerigi, and C. Theokas. 2005. 'Positive Youth Development.' Journal of Early Adolescence 25 (1): 10-6.

Li, Y., J. V. Lerner, and R. M. Lerner. 2010. 'Personal and Ecological Assets and Academic Competence in Early Adolescence: The Mediating Role of School Engagement.' Journal of Youth and Adolescence 39 (7): 801-15.

Markus, H., and P. Nurius. 1986. 'Possible Selves.' American Psychologist 41 (9): 954-69.

Mhatre, K. and R. Riggio. 2014. 'Charismatic and Transformational Leader- 
ship: Past, Present, and Future.' In The Oxford Handbook of Leadership and Organizations, edited by D. Day, 221-40. Oxford: Oxford University Press.

Mello, Z. R., and F. C. Worrell. 2006. 'The Relationship of Time Perspective to Age, Gender, and Academic Achievement among Academically Talented Adolescents.' Journal for the Education of the Gifted 29 (3): 271-89.

Mojić, D. 2014. 'Youth Unemployment in Economic And Social Crisis: Case of Serbia.' Limes Plus 11 (3): 209-21.

Mrđa, S. 2011. Kulturni život $i$ potrebe učenika srednjih škola u Srbiji. Beograd: Zavod za proučavanje Kulturnog razvitka.

Mueller, M. K., E. Phelps, E. P. Bowers, J. P. Agans, and M. P. Lerner. 2011. 'Youth Development Program Participation and Intentional SelfRegulation Skills: Contextual and Individual Bases of Pathways to Positive Youth Development.' Journal of Adolescence 34 (6): 1115-25.

Nurmi, J. E., M. E. Poole, and V. J. Kalakoski. 1994. 'Age Differences in Adolescent Future-Oriented Goals, Concerns, and Related Temporal Extension in Different Sociocultural Contexts.' Journal of Youth and Adolescence 23 (4): 471-87.

Nurmi, J. E, M. E. Poole, and R. Seginer. 1995. 'Tracks and Transitions - A Comparison of Adolescent Future-Oriented Goals, Explorations, and Commitments in Australia, Israel, and Finland.' International Journal of Psychology 30 (3): 355-75.

Nuttin, J., and W. Lens. 2014. Future Time Perspective and Motivation: Theory and Research Method. Leuven: Leuven University Press; Hillsdale: Erlbaum.

Polovina, N., I. Ćirović, and S. Jošić. 2013. 'The Issue of Migration According to Adolescents and Their Parents' Perceptions of Their Future.' In Proceedings of International Psychological Applications Conference and Trends - InPact 2013, edited by C. Pracana and L. Silva, 201-4. Madrid: World Institute for Advanced Research and Science.

Robitschek, C. 1998. 'Personal Growth Initiative.' Measurement and Evaluation in Counseling and Development 30 (4): 183-98.

- 1999. 'Further Validation of the Personal Growth Initiative Scale.' Measurement and Evaluation in Counseling and Development 31 (4): 197-210.

Robitschek, C., and S. W. Cook. 1999. 'The Influence of Personal Growth Initiative and Coping Styles on Career Exploration and Vocational Identity. Journal of Vocational Behavior 54 (1): 127-41.

Robitschek, C., W. Ashton, and C. Spering. 2012. 'Development and Psychometric Evaluation of the Personal Growth Initiative Scale 2.' Journal of Counseling Psychology 59 (2): 274-87. 
Schmid, K. L., E. Phelps, and R. M. Lerner. 2011. 'Constructing Positive Futures: Modeling the Relationship between Adolescents' Hopeful Future Expectations and Intentional Self-Regulation in Predicting Positive Youth Development.' Journal of Adolescence 34 (6): 1127-35.

Scott, G. M., D. C. Lonergan, and M. D. Mumford. 2005. 'Conceptual Combination: Alternative Knowledge Structures, Alternative Heuristics.' Creativity Research Journal 17 (1): 79-98.

Seginer, R. 2003. 'Adolescent Future Orientation: An Integrated CulturalEcological Perspective.' In Online Readings in Psychology and Culture, edited by W. J. Lonner, D. L. Dinnel, and S. A. Hayes. Bellingham, WA: Center for Cross Cultural Research. www.ac.wwu.edu/ culture/ readings.htm

- 2009. Future Orientation: Developmental and Ecological Perspectives. New York: Springer Science+Business Media, LLC.

Seginer, R., and S. Mahajna. 2004. 'How the Future Orientation of Traditional Israeli Palestinian Girls Links Beliefs about Women's Roles and Academic Achievement. Psychology of Women Quarterly 28 (2): 122135 .

Sgaramella, T. M., L. Ferrari, S. Santilli, and S. Soresi. 2017. 'Visions about Future: A New Scale Assessing Optimism, Pessimism, and Hope in Adolescents.' International Journal for Educational Vocational Guidance 17 (2): 187-210.

Sica, L. S., E. Crocetti, G. Ragozini, S. L. Aleni, and T. Serafini. 2016. 'Future-Oriented or Present-Focused? The Role of Social Support and Identity Styles on "Futuring" in Italian Late Adolescents and Emerging Adults.' Journal of Youth Studies 19 (2): 183-203.

Statistical Yearbook of the Republic of Serbia. (2014). Belgrade: Statistical office of the Republic of Serbia.

- (2017). Belgrade: Statistical office of the Republic of Serbia.

Stoddard, S. A., and J. Pierce. 2015. 'Promoting Positive Future Expectations during Adolescence: The Role of Assets.' American Journal Community Psychology 56 (o): 332-41.

Strange, J. M., and M. D. Mumford. 2002. 'The Origins of Vision: Charismatic versus Ideological Leadership.' Leadership Quarterly 13 (4):34378.

Strange, J. M., and M. D. Mumford. 2005. 'The Origins of Vision: Effects of Reflection, Models, and Analysis.' The Leadership Quarterly 16 (1): 121-48.

Sun, R. C., and D. T. Shek. 2012. 'Beliefs in the Future as a Positive Youth Development Construct: A Conceptual Review.' The Scientific World Journal, 1-8.

Taylor, S. 2011. 'Envisioning the Future and Self-Regulation.' In Predictions 
in the Brain: Using Our Past to Prepare for the Future, edited by M. Bar, 134-43. New York: Oxford University Press.

Tomanović, S., and D. Stanojević. 2015. Young People in Serbia: Situation, Perceptions, Beliefs and Aspirations. Belgrade: Friedrich Ebert Stiftung and Secons Development Initiative Group.

Türken, S., H. E. Nafstad, J. F. Phelps, and R. M. Blakar. 2016. 'Youth's Future Orientation and Well-Being: Materialism and Concerns with Education and Career among Rurkish and Norwegian Youth.' International Journal of Child, Youth and Family Studies 7 (3-4): 472-97.

Unemori, P., H. Omoregie, and H. R. Markus. 2010. 'Self-Portraits: Possible Selves in European-American, Chilean, Japanese and JapaneseAmerican Cultural Contexts.' Self and Identity 3 (4): 321-38.

Youngblade, L., C. Theokas, J. Schulenberg, L. Curry, I.-C. Huang, and M. Novak. 2007. 'Risk and Promotive Factors in Families, Schools, and Communities: A Contextual Model of Positive Youth Development in Adolescence Pediatrics.' Pediatrics 119 (1): 47-53.

Zimbardo, P. G., and J. N. Boyd. 1999. 'Putting Time in Perspective: A Valid, Reliable Individual-Differences Metric.' Journal of Personality and Social Psychology 77 (6): 1271-88.

This paper is published under the terms of the Attribution-

NonCommercial-NoDerivatives 4.o International (CC B Y-NC-ND 4.0)

License (http://creativecommons.org/licenses/by-nc-nd/4.o/). 


\section{Abstracts in Slovene}

\section{Pomen kulture za trajnostni razvoj}

Mitja Bervar

Namen tega prispevka je raziskati pomen in vlogo kulture v trajnostnem razvoju. Študija temelji na kvalitativni raziskavi, v kateri smo zajeli namenski vzorec treh skupin strokovnjakov, $\mathrm{z}$ uporabo intervjuja kot metode zbiranja podatkov. Ugotovitve študije kažejo, da kultura kot celosten in kompleksen sistem vrednot in razvojnih potencialov, spodbuja socialno kohezijo v družbi, krepi medkulturni dialog ter ob tem zagotavlja gospodarske učinke, ki se odražajo v trajnostnem razvoju. Zato bi bilo smiselno poleg ekonomskega, socialnega in okoljskega oblikovati tudi četrti gradnik - kulturo, ki bo celovito zaokrožila koncept trajnostnega razvoja.

Ključne besede: trajnostni razvoj, štirje stebri - gradniki trajnostnega razvoja, kultura, socialna kohezija, medkulturni dialog, kvalitativna študija

Klasifikacija JEL: D63, E61, L38, Z10

Managing Global Transitions 17 (3): 195-209

\section{Vplivnostni marketing kot sodobni fenomen}

v povezavi z upravljanjem statusa in ugleda

Josef Vodák, Martin Novysedlák, Lucia Čakanová in Miroslav Pekár

Namen prispevka je seznanjanje z najnovejšimi trendi na področju trženjskega komuniciranja. Domnevamo lahko, da uporaba novih oblik promocije preko družbenih medijev narašča, kar vodi v nove izzive $\mathrm{v}$ tekmovanju za pozornost potrošnikov. Razvijajoča se skupnost vplivnežev ima pomembno moč pri dojemanju blagovnih znamk in podjetij, zato lahko v veliki meri vpliva na njihov status in ugled. Zaradi novih možnosti se povečuje tudi potreba po ustreznih komunikacijskih strokovnjakih, ki bi delovali na področju nenehnega sodelovanja s ciljnimi strankami preko različnih družbenih spletnih kanalov.

Ključne besede: vplivnostni marketing, družbeni mediji, status in ugled Klasifikacija JEL: M31, M37

Managing Global Transitions 17 (3): 211-220

\section{Dejavniki, ki vzpodbujajo trgovce $k$ ponavljanju promocij} skupinskih ponudb 
Nina Angelovska, Sasho Josimovski in Lidija Pulevska Ivanovska

Namen študije je bil raziskati, kako določeni dejavniki vplivajo na odločitev trgovcev, da ponavljajo skupinske ponudbe in uporabo spletnih strani za skupinske nakupe v promocijske namene. Raziskava je potekala na podlagi sekundarnega in primarnega zbiranja podatkov. Primarni podatki so bili zbrani z uporabo vprašalnika, namenjenega podjetjem, ki izvajajo vsakodnevne promocije ugodnih ponudb. Za analizo podatkov je bil uporabljen model tobit. Rezultati kažejo, da trgovci ponavljajo ugodne ponudbe glede na donosnost sklenjenih poslov, porabo, ki je večja od osnovne in novih kupcev, ki jih ugodna ponudba privabi; seveda pa na tem področju obstajajo razlike med različnimi poslovnimi kategorijami. Ugotovitve te študije so lahko koristne na področju združevanja podjetij in pri izboljšavah poslovanja malih in srednje velikih podjetij, ki dnevno promovirajo ugodne ponudbe.

Ključne besede: trgovci na drobno, dobičkonosnost, marketing, tobit model, model skupinskega nakupa, promocije, Makedonija

Klasifikacija JEL: M31, M21

Managing Global Transitions 17 (3): 221-238

\section{"Vizija osebne prihodnosti« kot orodje za podporo mladostnikom med prehodom v odraslo dobo \\ Nada Polovina in Smiljana Jošić}

Prispevek opisuje področje Vizije osebne prihodnosti (VPF), instrumenta, namenjenega ocenjevanju kognitivne jasnosti, prepričanja v realizacijo in samo-usmerjenosti mladostnikovega razmišljanja o osebni prihodnosti. 13-točkovna lestvica je bila uporabljena pri delu s 1.969 srbskimi mladostniki, z namenom raziskovanja splošnih vidikov njihovih pričakovanj glede lastne prihodnosti. Rezultati kažejo, da mladostniki izpostavljajo predvsem motivacijski in vodilni potencial lastne vizije prihodnosti. Med raziskovalnim procesom sta posebej izstopali dve faktorski strukturi (poimenovani motivacijsko optimistična in kognitivno strašljiva), vendar so mladostniki vsak dejavnik poudarili na drugačen način. Uporabnost lestvice je bila obravnavana v okviru mladinskega dela in oblikovanja posebnih programov, namenjenih podpori razvoja mladih.

Ključne besede: prihodnje razmišljanje, lestvica Vizija osebne prihodnosti, mladostniki, pozitiven razvoj mladih

Klasifikacija JEL: I20, 015

Managing Global Transitions 17 (3): 239-258 